\title{
Perceptions of pre -service elementary teachers about social studies instructional activities and content areas
}

Philip H. Adkins

West Virginia University

Follow this and additional works at: https://researchrepository.wvu.edu/etd

\section{Recommended Citation}

Adkins, Philip H., "Perceptions of pre -service elementary teachers about social studies instructional activities and content areas" (1999). Graduate Theses, Dissertations, and Problem Reports. 3158.

https://researchrepository.wvu.edu/etd/3158

This Dissertation is protected by copyright and/or related rights. It has been brought to you by the The Research Repository @ WVU with permission from the rights-holder(s). You are free to use this Dissertation in any way that is permitted by the copyright and related rights legislation that applies to your use. For other uses you must obtain permission from the rights-holder(s) directly, unless additional rights are indicated by a Creative Commons license in the record and/ or on the work itself. This Dissertation has been accepted for inclusion in WVU Graduate Theses, Dissertations, and Problem Reports collection by an authorized administrator of The Research Repository @ WVU.

For more information, please contact researchrepository@mail.wvu.edu. 
Perceptions of Pre-service Elementary Teachers

About Social Studies Instructional Activities and Content Areas

Philip H. Adkins

\begin{abstract}
Dissertation submitted to the College of Human Resources and Education at West Virginia University in partial fulfillment of the requirements for the degree of
\end{abstract}

\author{
Doctor of Education \\ in \\ Curriculum and Instruction \\ C. Kenneth Murray, Ph.D., Chair \\ Ronald V. Iannone, Ed.D. \\ Perry D. Phillips, Ed.D. \\ W. Scott Bower, Ph.D. \\ Ronald C. Althouse, Ph.D.
}

Department of Educational Theory and Practice

Morgantown, West Virginia

1999

Keywords: Social Studies, Perceptions, Instructional Activities, Elementary Social Studies, Pre-Service Teachers, Social Studies Content 


\title{
ABSTRACT
}

Perceptions of Pre-service Elementary Teachers About Social Studies Instructional Activities and Content Areas

\author{
Philip H. Adkins
}

This study was designed to investigate perceptions held by pre-service elementary teachers about instructional activities and content areas for the social studies. Four major questions were addressed: (1) What do respondents perceive to be the classroom activities with the most educational value?; (2) What do respondents believe students find to be the most enjoyable activities?; (3) What do respondents say are the classroom activities they would most prefer to use at the various grade levels?; and (4) What do respondents say are the most preferred content areas for elementary social studies?

The sample for this study consisted of 80 pre-service elementary teachers at West Virginia University. These students had sequenced through the teacher education program and were anticipating their internship placement. The population was primarily traditional college age females in their senior or fifth year with a grade point average of 2.5 to 4.0 , with most falling in the 3.0 to 3.49 range.

Respondents preferred instructional activities for their educational value, not those which might be more popular with students. Their preferences appear to be based on age/grade/cognitive ability of students and not on the basis of activities that might be easier to grade or which might facilitate classroom control. Their choices were not limited to just a few activities.

In terms of preferred content areas, the respondents, across all grade levels, most preferred current events, drug education, and multicultural education. They also endorsed the study of conflict resolution and values education for Grades K-3, U. S. history for Grades 4-6 and 7-8, state history for Grades 4-6, and career education for Grades 7-8. They least preferred philosophy, religion, and law-related education across all grade levels. Other lowest ranked instructional content areas were anthropology, archeology, economics, and political science. A comparison of respondent ranking of the content areas with instructional goals and objectives published by the West Virginia Department of Education shows minimal congruence.

In conclusion, this author found the data to show the respondents as having a discerning and sophisticated knowledge to deal with their future responsibilities: a very positive message about social studies in the new millennium. 


\section{ACKNOWLEDGEMENTS}

I wish to thank the members of my dissertation committee for their understanding and support. The members were Dr. Ronald Althouse, Dr. Walter Scott Bower, Dr. Ronald Iannone, and Dr. Perry Phillips.

For empathy, support, and more patience that can easily be explained, I wish to thank Dr. Kenneth Murray, the Chairman of the committee and longtime advisor. 
Table of Contents

List of Tables ...................................................................... vi

List of Figures .................................................................... vii

Chapter 1. Statement of the Problem............................................... 1

Nature and Significance of the Study ..................................... 2

Research Questions .......................................................... 4

Definition of Terms ....................................................... 5

Limitations of the Study ............................................... 6

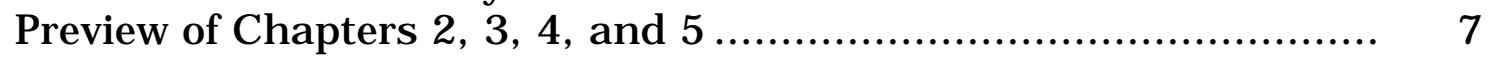

Chapter 2. Review of the Related Literature...................................... 8

The Nature and Content of the Social Studies.......................... 8

Teacher Preference for Instructional Activities and

Content Areas ............................................................. 12

Instructional Activities ............................................... 19

Reading and Discussing the Text................................. 20

Reinforcing Activities: Seatwork .................................... 21

Reinforcing Activities: Class Discussion........................... 21

Using Games, Simulations or Computer Games ................... 22

Viewing Slides, Filmstrips, Movies or Videos...................... 23

Listening to Tapes, Lectures or Dramatic Readings by the

Teacher or Resource Person ....................................... 24

Field Trips.............................................................. 24

Research Projects .................................................. 25

Issue Focused Interaction....................................... 26

Oral Language Experience ......................................... 26

Performing from Scripts ......................................... 27

Constructing/Making............................................. 27

Art-related Activities................................................ 28

Writing Activities ................................................... 28

Chapter 3. Methodology ....................................................... 33

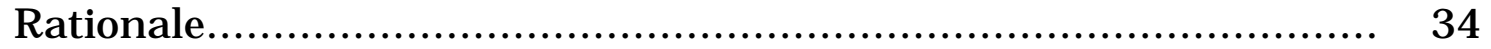

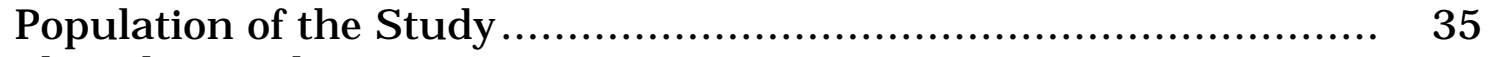

The Pilot Study ............................................................. 35

The Research Protocol ..................................................... 37

The Data Gathering Instrument.................................... 38

Procedure Used in the Analysis of Data .............................. 40

Chapter 4. Presentation of the Data .............................................. 43

Population Variables ..................................................... 54 
Chapter 5. Summary, Conclusions, and Implications ......................... 57

Summary of Major Findings ......................................... 58

Conclusions and Implications........................................... 71

Teacher Education ............................................. $\quad 72$

Preconceptions and Background ................................ 74

Further Research ................................................... 75

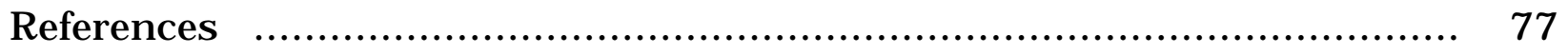

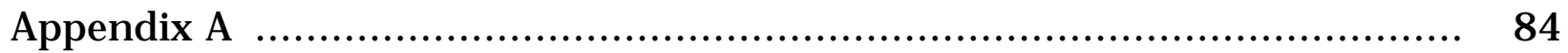

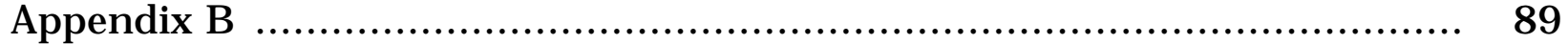

Tables 1 through 25 
List of Tables

Tables

1. Summary of Responses to Question 1: Educational Value

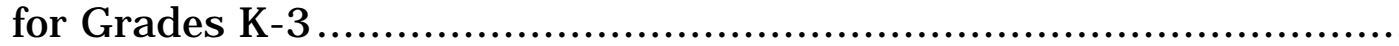

2. Summary of Responses to Question 1: Educational Value for Grades 4-6

3. Summary of Responses to Question 1: Educational Value for Grades 7-8...

4. Summary of Responses to Question 1: Comparison of Grade Level Rankings of Educational Value

5. Summary of Responses to Question 2: Enjoyable Activities for Grades K-3

6. Summary of Responses to Question 2: Enjoyable Activities for Grades 4-6

7. Summary of Responses to Question 2: Enjoyable Activities for Grades 7-8

8. Summary of Responses to Question 2: Comparison of Grade Level Rankings of Enjoyable Activities...

9. Summary of Responses to Question 3: Preferred Activities for Grades K-3

10. Summary of Responses to Question 3: Preferred Activities for Grades 4-6

11. Summary of Responses to Question 3: Preferred Activities for Grades 7-8.

12. Summary of Responses to Question 3: Comparison of Grade Level Rankings of Preferred Activities

13. Summary of Responses to Research Questions 1-3 for Grades K-3

14. Summary of Responses to Research Questions 1-3 for Grades 4-6 
List of Tables (Continued)

15. Summary of Responses to Research Questions 1-3 for

Grades 7-8

16. Summary of Responses to Question 4: Content Areas for Grades K-3

17. Summary of Responses to Question 4: Content Areas for Grades 4-6

18. Summary of Responses to Question 4: Content Areas for Grades 7-8

19. Summary of Responses to Question 4: Comparison of Most Preferred Content Areas for the Various Elementary Grades

20. Summary of Responses to Question 4: Comparison of Least Preferred Content Areas for the Various Elementary Grades

21. Summary of Responses: Comparison of Rankings for Educational Value, Preferences, and Perceived Student Enjoyment for Kindergarten - Grade 8

22. Summary of Secondary Social Studies Teachers' Responses: Comparisons of Rankings for Educational Value, Preferences, and Perceived Student Enjoyment for Secondary Grades (Murray, 1997)

23. Summary of In-service Social Studies Teachers' Responses: Comparisons of Rankings for Educational Value, Preferences, and Perceived Student Enjoyment for Kindergarten - Grade 8 (Alleman and Brophy, 1995)

24. Tallied Objectives for Goals and Objectives for West Virginia Schools (Marockie, 1995)

25. Ranked Objectives for Goals and Objectives for West Virginia Schools (Marockie, 1995) 


\section{List of Figures}

Figures

1. What Social Studies Instructional Activities Do Pre-service Elementary Teachers Perceive as Having the Most Educational Value for Teaching at the Various Elementary Grades?

2. What Social Studies Instructional Activities Do Pre-service Elementary Teachers Perceive as Providing the Most Enjoyment for Students in the Various Elementary Grades?

3. What Social Studies Instructional Activities Do Pre-service Elementary Teachers Prefer to Use at the Various Elementary Grades?

4. The Five Highest (Top) Ranked Instructional Content Areas and the Five Lowest (Bottom) for the Various Elementary Grade Clusters

5. Descriptive Population Variables of Respondents

6. Highest Ranked Instructional Activities for Teacher Preference and Associated Skill(s)

7. Lowest Ranked Instructional Activities for Teacher Preference and Associated Skill(s) 


\section{CHAPTER 1}

Chapter 1 begins with a statement of the problem, which is followed by the nature and significance of the study. The research questions, developed from the related literature, are presented. The definitions of terms used in this study and the limitations of the study are explained. The chapter concludes with an overview of Chapters 2 through 5.

\section{Statement of the Problem}

Since the science fiction musing of 2001: A Space Odyssey, the $21^{\text {st }}$ century has seemed to be a symbol of a massive change in technology and human achievement: as if the United States and the world will suddenly be dramatically transformed. As we look forward to the new millennium, our imaginations are stimulated as we anticipate the future. Speculation is rife in all areas of life. Change is constant. This is no less so in education than in other aspects of life and it is especially so in the social studies (Haas and Laughlin, 1997, p. 7). This investigation explores how future elementary school teachers rank the educational value, the perceived enjoyment by students and their personal preferences of various social studies classroom activities. It further investigates what these pre-service teachers most prefer and least prefer of the various social studies basic content areas. The results should be of interest to teachers of teachers and to persons or groups who attempt to promote various activities or content areas in the social studies. 


\section{Nature and Significance of the Study}

Most of the research dealing with elementary social studies education has looked at "social education" which, although it has included "social studies education," has generally meant "socialization" of the students (Bloch, 1986, p. 91). This research attempts to look for the methods and content that preservice elementary teachers perceive as important in elementary social studies.

This is appropriate for several reasons. First, the elementary social studies provide the basis for students' knowledge and enjoyment in the secondary school social studies courses. Secondly, students' prior experiences in schools build perceptions about teaching which is the basis of their further learning and these preconceptions can form their decisions about teaching before they have the experiences appropriate to guide their decision making in these areas (The Benedum Project, 1994, p. 6). Thirdly, standards, while devised for $\mathrm{K}-12$, seem not to be emphasized at the elementary level where teachers have such a plethora of fields to cover that they seem to be given more autonomy or freedom in what they can or will cover and how they will do so (Grant, 1996, p. 261). Even in a time of flux with calls for change and various standards and arguments being proffered, it is still ultimately the classroom teacher with his/her perceptions that make the call regarding content and methods.

To get some idea of the nature of elementary social studies content and methods in the $21^{\text {st }}$ century, students who will be teaching then will be asked 
for their perceptions of preferred curriculum content and instructional activities. This, then, is an attempt to discern those aspects which pre-service teachers find to be important. Although there are many crosscurrents influencing teachers' practices, Grant, as reported in the Benedum Report in 1994 (p. 6) has found that teachers have great latitude in their curriculum decisions. Stephen J. Thornton (1991) has argued that these decisions are idiosyncratic:

The teacher's beliefs about schooling, his or her knowledge of the subject area and of available materials and technique, how he or she decides to put these together for the classroom, out of that process of reflection and personal inclination comes the day-byday classroom experiences of students. This is not to say that social studies classes are not affected by factors such as the characteristics of the students enrolled, but only emphasize that the teacher plays the primary structuring role.

Indeed, Thornton has called the teacher the "curricular-instructional gatekeeper" in social studies. This gate-keeping has three components, he argues: “(1) beliefs concerning the meaning of social studies, (2) decisions concerning planning and (3) decisions concerning instructional strategy" (Thornton, 1991, p. 237-238). This gate-keeping of instructional content and activities is based on a personal perspective or frame of reference. This 
perspective is based on personal knowledge, not curricular standards or the content of education classes. Similarly, Goodman and Adler (1985, p. 1) suggested that "official conceptions of social studies have little to do with student teachers' beliefs and actions in the classroom."

\section{$\underline{\text { Research Questions }}$}

The following research questions will guide the study.

1. What social studies instructional activities do pre-service elementary teachers perceive as having the most educational value for teaching the various elementary grades?

2. What social studies instructional activities do pre-service elementary teachers perceive as providing the most enjoyment for students in the various elementary grades?

3. What social studies instructional activities do pre-service elementary teachers prefer to use at the various elementary grades?

4. What do pre-service elementary social studies teachers say are the most preferred social studies curriculum content areas to present at the various elementary grades? 
The study will address the research questions to determine how the sample of pre-service elementary teachers perceive social studies instructional activities and instructional content areas.

\section{Definition of Terms}

For the purposes of this study the following definitions are used:

Content Areas--the various disciplines and sub-disciplines of the social sciences as well as the various humanities, interdisciplinary, and problem oriented topics from which material(s) have been taken to provide the curriculum in the elementary social studies.

Educational Value--refers to which instructional activities the respondent perceives as having greater importance for the course content for the student. Enjoyable Activity--refers to which instructional activities the respondent perceives that the student would take more pleasure in doing. Instructional Content--the material chosen from the content areas to be included in the course curriculum.

Instructional Activities--the various teaching methods available to the elementary social studies teacher and listed on the questionnaire.

Pilot Study--a small-scale test of the questionnaire (data-gathering instrument) of this study prior to its formal administration to determine design flaws in the questionnaire or its administration protocol.

Population--the group from whom the data was gathered. 
Population Variable--descriptions delineating personal characteristics for each representative found in the population.

Preferred Activity--refers to which instructional activities the respondent would personally rather use.

Respondent(s)--person(s) in the population who answered the questionnaire for the study.

\section{Limitations of the Study}

1. The study is limited by the source of data used to investigate the research questions. Data were collected in classes representing the required sequence of courses in teacher education for pre-service teachers immediately before beginning their student teaching placement.

2. The classes in which questionnaires were distributed were only those in which elementary education majors were required to take part. Courses required of secondary education majors were not included.

3. The study is limited to undergraduate elementary education majors in teacher education programs at West Virginia University. 


\section{Preview of Chapters $2,3,4$, and 5}

Chapter 2 gives a summary of the literature related to this investigation. This review focuses on three areas of importance to this study: (1) the nature and content areas of the social studies, (2) teacher preferences for instructional activities and content areas, and

(3) instructional activities.

Chapter 3 offers a description of the methodology used in the study and the development of the instrument. The instrument and its format are explained. The protocol for the study and the population used is described. The procedures for analyzing the data and its limitations are presented.

Chapter 4 provides an analysis of the data obtained. Narrative description and data summaries are used to present the findings.

Chapter 5 gives an overview of the study and summarizes the major findings. Discussion of the findings follows along with the conclusions and implications for further study. 


\section{CHAPTER 2}

\section{$\underline{\text { Review of Related Literature }}$}

The objective of the present study is to describe the perceptions of preservice elementary teachers about social studies instructional activities and content areas. The review of the related literature is presented in this chapter. It has been organized into three areas appropriate to the study:

(1) the nature and content areas of the social studies, (2) teacher preferences for instructional activities and content areas, and (3) instructional activities.

\section{The Nature and Content of the Social Studies}

We are currently seeing calls for school reforms at the national level (America 2000, 1991, p. 3). These include calls for national standards in testing (America 2000, 1991, p. 13): "the buzz of (curriculum) standards talk" is loud today (Grant, 1996, p. 237). The trouble, of course, has been that in creating standards one must do so within certain parameters. Thus, the history of attempting to set standards has also been the history of attempting to define the social studies. Susan Adler has said, "Social Studies standards address what is unique and essential to the social studies program" (Adler, 1994, p. 17).

Probably the first definition of the social studies with any degree of widespread notice and acceptance in the field of social studies education was 
developed by the 1916 Social Studies Committee of the National Education Association (NEA), Commission on Reorganization of Secondary Education. It read, "The social studies are understood to be those whose subject matter relates directly to the organization and development of human society and to man as a member of social groups" (Jenness, n.d., p. 26). While other definitions of the social studies have attempted to list the various social science disciplines involved (Expectations of Excellence, 1994, p. viii), some definitions have emphasized the simplifications of these social science content areas for teaching at lower levels (Stuckey, p. 13). Other definitions have stressed the purpose to which their content should be used, i.e., decision-making skills especially in regard to civic competence (Barr, et al., 1977, p. 64).

While there is no real consensus on how to define the social sciences, recently two characteristics have become identified as the basis on which standards for the social studies have been built (Davis, 1996, p. 18). These were written by the Task Force of the National Council for the Social Studies (NCSS) and approved by the Board of Directors in 1994 (Expectations of Excellence, 1994, p. viii). These two characteristics which "distinguish social studies as a field of study are (1) it is designed to promote civic competence, and (2) it is integrative, incorporating many fields of endeavor" (Barr, et al., 1997, p. 69). The NCSS Task Force standards were voluntary and intended as guides, but they do represent some degree of synthesis. They were developed in "collaboration with social studies educators in the field, scholars in the 
academic disciplines, and the general public" (Expectations of Excellence, 1994, p. xvii).

This has not always been the case. During the era of national committees, 1890-1940, "authorities" were used to make determinations of what should be taught, and how it should be taught. The "social studies components" recommended by the Committee of ten of the National Education Association (NEA) in 1893 called for biography and much history. The American Historical Association (AHA) Committee of seven in 1899 continued history as an emphasis and added American government, civics, consumer economics, and problems of democracy. These were also called for by the NEA's Commission on Reorganization of Secondary Education in 1916. This Commission actually used the term social studies. But it still was heavy in its emphasis on history and it is little wonder that the AHA's Commission on Social Studies in the Schools of 1926 affirmed the 1916 report.

These early national committees were followed by a series of social studies curriculum projects from the various social science disciplines. "Almost overnight . . . the social studies became the social sciences" (Barr, et al., 1977, p. 34). Curriculum Task Forces representing the national organizations of the various social sciences became active. With funding from the United States Office of Education and other sources, eventually more than fifty such projects were funded (Barr, et al., 1977, p. 43). These were followed in the late 1960s and early 1970s by an emphasis on moral and/or value education. This was succeeded by multidisciplinary studies, e.g., 
Environmental Studies and Women's Issues. Starting in the early 1980s, the pendulum swung back to emphasizing single disciplines (Mahood, et al., 1991, p. 11), and the new curriculum standards from the NCSS do not dismiss them. Rather, "teachers and curriculum designers are encouraged just to establish their program frameworks using the social studies standards as a guide, and then to use the standards from history, geography, civics, economics, and other disciplines to guide the development of grade level strands and courses. Using all of these standards in concert with one another allows educators to give adequate attention to other integrated and single discipline configurations" (Expectations of Excellence, 1994, pp. vii-viii).

It may be appropriate to distinguish these more general or thematic standards of the NCSS from those standards promulgated by one of the disciplines. The National Geography Standards, for example, consist of six "essential elements" and eighteen standards. "This framework, derived from national and international resources, details the knowledge, skills, attitudes, values, and dispositions of a geographically informed person" (Freese, 1997, p. 22). Those elements listed were: (1) The World of Spatial Terms, (2) Places and Regions, (3) Physical Systems, (4) Human Systems, (5) Environment and Society, and (6) The Uses of Geography.

On the other hand, the 1994 social studies standards approved by the NCSS were organized into the following more broadly based themes. These themes were culture, time, continuity, and change; people, places, and environments; individual development and identity; individuals, groups, and 
institutions; production, distribution, and consumption; power, authority, and governance; global connections; science, technology, and society; civic ideals and practices (Expectations of Excellence, 1994, pp. x-xii). This is essentially where we are at this point in time.

The definition of the social studies has undergone little change for years and has strong reference to the social science underpinnings. The definition found in the U. S. Office of Education's Standard Terminology for Curriculum and Instruction is typical: the social studies are comprised of aspects of History, Economics, Political Science, Sociology, Anthropology, Psychology, Geography, and Philosophy (Barr, et al, 1977, p. 2).

\section{Teacher Preference for Instructional Activities and Content Areas}

"Issues relating to the design, selection and evaluation of learning activities have been relatively neglected by education research and scholars" (Brophy and Alleman, 1991, p. 9). In fact, Brophy and Alleman felt so strongly about this lack of interest in the selection and evaluation of instructional activities in the article from which the above statement was taken that they introduce a framework to aid in the analysis and evaluation of instructional activities.

This framework is essentially a list of "principles for design, selection and evaluation of activities" (Brophy and Alleman, 1991, p. 14) in table form. The table includes five sets of principles. These sets of principles include (1) Primary principles, or necessary criteria, (2) Secondary principles or desirable 
criteria, (3) Principles that apply to sets of activities even when they do not necessarily apply to individual activities, as the authors, intend the first two sets of activities to apply, (4) Additional principles or alternate criteria that obtain from particular philosophies held by the teacher or school, and (5) Principles that apply to implementation goals (Brophy and Alleman, 1991, p. 14). Interesting, and no doubt useful, their framework does not deal with the way instructional activities are currently chosen or what is chosen.

"Primary Elementary Social Studies Instruction: A Status Report" is a study exploring the utilization of various methods of social studies instruction. For this study questionnaires concerning methods of social studies instruction were mailed to teachers in seven mid-western states. This report based on returns (42\%) from 3,000 questionnaires on the various methods used in the 1993 primary social studies classrooms found possibly predictable, but previously undocumented results. Maps, globes, supplementary resource books, worksheets, films, filmstrips, picture sets, videotapes, learning centers, field trips, games, guest speakers, and television were all found to be used in the elementary social studies classrooms (Finkelstein, et al., 1993, p. 67). In 1989 the report Charting a Course: Social Studies for the $21^{\text {st }}$ Century by the Curriculum Task Force argued what the ideal social studies program should include. As Finkelstein reported, the Task Force strongly suggested that reading books, stories and bibliographies, drawing, building, role playing, writing, and participating in activities with music was appropriate curriculum for a strong program. Finkelstein, et al., did 
not specifically check on the status of these activities (Finkelstein, et al., 1993, p. 93).

Today the integration of the social sciences, the Internet, and teaching helps move the profession into the new century. A 1998 article, by C. Sunal, Smith, D. Sunal and Britt (p. 13), posits five levels of Internet activity: "personal use, sharing material with students, incorporating material into units, facilitating student-directed projects, and student-initiated and directed projects. The Internet has become a serious tool for the educator but the first three levels are the most widely used." The use of technology as an instructional activity for the social studies is not common. Interestingly, West Virginia includes the understanding and use of technology by students as social studies objectives (Marockie, 1995).

A review of seven textbooks of social studies education for elementary teachers found only two with no reference to computers at all (Martorella, 1994; Walsh, 1980). Most of the texts gave examples of activities that allowed the computer to be a tutor with activities such as drills, tutorials, instructional games, and simulations (Hoge, 1996; Woolever and Scott, 1988; Parker and Jarolimek, 1997; Kaltsounis, 1987). While computer simulations were an obvious choice for social studies activities, many suggested activities simply used the computer as a tool for traditional activities, i.e., networking information, graphing, and writing. For example, see Kaltsounis (1987, p. 280). This, then, does not make the use of technology and its understanding become a social studies objective as the State of West Virginia explicitly states. 
However, most teachers seem to see the computer as a tool or means rather than an educational activity. This is reflected in Finkelstein's list, the Sunal statement, and the Alleman and Brophy list of instructional activities.

The Alleman and Brophy list culminated from continuing research into learning activities that began with a review of theory and research especially with regards to the social studies (Brophy and Alleman, 1991). In a subsequent study they investigated reports of learning activities experienced in elementary social studies by college students (Alleman and Brophy, 1994). In this research, they found that college students remembered more from the middle grades, but that cognitive learning associated with their memories were most impressive for the early grades and least so for the upper grades. Although they coded their data for content domains which are not as precise or as manifold as the list Murray used in his study (Murray, 1998) and for learning outcomes, their activity typology is of concern here.

In this early formulation their activity types were:

1. multiple (a curriculum unit or a set of several related activities)

2. receiving information (from a teacher, a presentation research person or a media)

3. seatwork (reading and answering questions from the text, filling out dittos or worksheets) 4. research (reading to an oral or written report) 
5. construction (of dioramas, displays, models, or artistic products)

6. field trips

7. discussion/debate

8. role enactment (pageants, imitations of cultural practices or other role playing that involved following scripts or imitating models)

9. realistic simulations and applications (that required students to solve problems or make decisions rather than just follow a script or imitate a model) 10. other (including singing, eating cultural foods, and engaging in patriotic activities)

This Alleman and Brophy paper (with the ten specific instructional activities categories indicated) became the basis for the more inclusive list used for investigation of preference, enjoyment, and educational value of the 14 instructional activities as reported by in-service teachers (Alleman and Brophy, 1995). Alleman and Brophy generated a more inclusive list of 14 elementary instructional activities in 1995 (pp. 14-15).

This list (Alleman and Brophy, 1995, pp. 16-17) included:

1. reading and discussing the text

2. reinforcing activities: seatwork (crossword puzzles, fill-in-the-blank, matching, locating and 
coloring correct answers, vocabulary and skill reinforcement)

3. class discussions (open-ended questions, reading and interpreting map, graph, cartoon, or paragraph)

4. using games/simulation or computer games

5. viewing slides, filmstrips, movies or videos

6. listening to tapes, lectures, or dramatic readings

by the teacher or resource person

7. field trips

8. research project

9. issue focused interaction (debate, mock trial, panel discussions)

10. oral language experience (story-telling with pictures or puppets, writing/singing songs, or conducting structured interviews)

11. performing from scripts (plays, puppet shows, pageants)

12. constructing/making (dioramas, panoramas, shadow boxes, displays, salt/flour maps, artifacts, weaving, drying fruit, and making soup)

13. art-related activities (painting and drawing) 
14. writing activities (journals, logs, letters to pen pals, letters requesting information, writing plays or dialogue)

Those social studies content areas for evaluation have been derived from listings used by Murray (1998). Murray developed his list from content analysis of elementary social studies pre-service teachers' textbooks, from the NCSS definitions of social studies, and from professional understandings as professor and researcher in social studies education (Murray, 1999). His listings include traditional social science fare such as History but also multidisciplinary content areas such as Future Studies. The Murray social studies content areas that were evaluated by pre-service teachers in this study were:

1. Anthropology

2. Archeology

3. Career Education

4. Conflict Resolution

5. Current Events

6. Drug Education

7. Economics

8. Energy Environmental Education

9. Future Studies

10. Gender Issues

11. Geography 
12. Global Education

13. Humanities

14. Law-related Education

15. Multicultural Education

16. Philosophy

17. Political Science

18. Psychology

19. Religion

20. Sociology

21. State History

22. U. S. History

23. Values Education

24. Volunteer/Required Social Service Projects

25. World History

\section{$\underline{\text { Instructional Activities }}$}

The 14 activities are discussed below as they are currently described in the textbooks. Instructional activities are also called teaching strategies. What students do in response to a teaching strategy is sometimes called a learning activity (Woolever and Scott, 1988, p. 212). However referenced, instructional activities allow for variety in instruction. Variety in the classroom has been shown to enhance student interest thereby producing more active student 
involvement and, thus, maximizing learning. Woolever and Scott (1988, p. 214) say that research shows

that social studies teachers, left to their own devices, use only a limited number of teaching strategies, that students find social studies "boring," and that students suggest that their boredom could be relieved if teachers would use a variety of teaching techniques.

The variety of (14) instructional activities compiled by Alleman and Brophy are discussed below as they are currently described in the elementary social studies education textbooks.

\section{Reading and Discussing the Text}

It is argued that social studies textbooks are not an easy read even when written at a suitable level. This is because of the need for substantive content which will, of necessity, introduce new concepts (Parker and Jarolimek, 1997). Most authors (Hoge, 1996, pp. 46-49; Sunal and Hess) seem to follow the lead of Alleman and Brophy (1994) who reported that recent emphasis on the use of children's literature as an aid to social studies textbooks may have negative results. They noted that much effort may be put into a literary selection that is trivial or only a narrow aspect of the topic being studied. Textbooks are a fact of life for teachers and possibly a major curriculum determinant (Sunal and Haas, 1993, p. 104) for the elementary social studies. They are discussed by 
most authors of textbooks on the teaching of social studies at the elementary level (see also Hoge, 1996; Kaltsounis, 1987; Woolever and Scott, 1988).

Reinforcing Activities: Seatwork (crossword puzzles, fill-in-the-blank, matching, locating and coloring correct answers, vocabulary and skill reinforcement).

Alleman and Brophy (1994) make several disparaging remarks about this particular activity noting that most students in their research who remembered the seatwork activities could remember no learning outcomes associated with them. Most of the college textbook authors seem to avoid "seatwork," but Hoge (1996, pp. 74-75) and Parker and Jarolimek (1997, pp. 338-339) both encourage its use for vocabulary development. Hoge, for example, specifically states that "students should use crossword puzzles, word-finds, the spelling/vocabulary baseball games, people bingo, classroom concentration, and other instructional devices to reinforce the learning of social science ... vocabulary."

Reinforcing Activities: Class Discussion (open-ended questions, reading and interpreting a map, graph, cartoon or paragraph).

Class discussion allows the teacher to evaluate the student and the student to practice skills (Sunal and Haas, 1993, pp. 138-140). It gets support 
from those who write the textbooks on how to teach (Hoge, 1996; Parker and Jarolimek, 1997; Martorella, 1994). Kaltsounis (1990,

pp. 232-242) argued for class discussion as the educational activity for dealing with moral education and for controversial issues. Wilen, in a Review of Pedagogical Perspectives (1988, p. 314) says that "teachers tend to excessively control discussions" and "that preservice and inservice teachers need to be trained in, and have an opportunity to apply, those skills that contribute toward conducting effective discussions." Teachers can make more effective discussions, he says, by encouraging questions, probing student responses for clarification and for rational support of knowledge claims, and even arranging the classroom to make it easier to communicate.

\section{Using Games, Simulations or Computer Games}

A simulation is an exercise that models as closely as possible some aspect of reality. When, in addition, a simulation includes strategy, chance and competition, it is referred to as a simulation game (Hoge, 1996, p. 91). Although this gives rise to some concern that the fun might overshadow the learning objective (see, for example, Hoge, 1996, pp. 91-93) there is generally a great deal of support for the various games and simulations in the education textbooks (Parker and Jarolimek, 1997; Kaltsounis, 1987; Martorella, 1994; Sunal and Haas, 1993). Diem (1997, p. 99) has written that simulation is "one of the best classroom teaching tools." He argues, 
Through the use of a scenario that can be displayed verbally and graphically on a computer screen ..., the student is able to simulate, or recreate, lifelike activities in an interactive mode. A decision must be made based on the given story, and then the consequences unfold. The use of simulations encourages inductive learning by allowing the learner to look at a series of complex processes that go beyond mere memorization of factual information. Hypothesis formation and higher level thinking strategies are developed through this type of teaching.

\section{Viewing Slides, Filmstrips, Movies or Videos}

This can include videotaping class activity to allow the teacher to give specific feedback to their students (Parker and Jarolimek, 1997, pp. 311-312). Overall this activity is well presented in the textbooks for future teachers (Hoge, 1996; Martorella, 1994; Walsh, 1980; Woolever and Scott, 1988). It is generally accompanied by guidelines which include the need for the teacher to preview the material(s) and to "use audiovisual aids only when educational objectives require them" (Kaltsounis, 1987, pp. 250-260). 
Listening to Tapes, Lectures or Dramatic Readings by the Teacher or Resource Person

There seems to be little support for this activity at least in its traditional form. The two sets of authors (Sunal and Haas, 1993; Woolever and Scott, 1985) who discuss its use warn about length of lecture as related to the age of the student: the smaller the child the smaller the lecture. Woolever and Scott (1988, p. 227) specifically warn that "children learn by doing and those in the early grades are most in need of 'active' learning experiences."

\section{Field Trips}

Although some prefer the term "study trip" (Walsh, 1980, pp. 94-98) and some encourage camping trips, also (Kaltsounis, 1987, p. 294), everybody loves field trips (Hoge, 1996; Parker and Jarolimek, 1997; Martorella, 1994; Woolever and Scott, 1988). Typically, textbook authors feel compelled to remind their pre-service teacher readers what experienced teachers know, "which is that in order to reinforce and expand classroom-based learning, an educational trip needs to be carefully planned, executed and followed up" (Walsh, 1980, p. 95). Walsh lists ten procedures to make a study/field trip worthwhile and devotes an entire page to the tenth procedure: follow-up activities. The ten procedures which Walsh describes which "many teachers follow" are (1) Decide on the desired learning outcomes from the visit, (2) When possible, talk with other teachers who have visited the same place, (3) Make a pre-trip visit to the destination, (4) Confer with the person who will guide the children's visit, (5) 
Transportation arrangements are best made well in advance of the trip, (6) Parents must be contacted to give permission for the child's participation, (7) Contingency plans are made to prepare as much as possible for the unexpected, (8) Just prior to the trip, the teacher prepares the class for the trip as a learning experience, (9) Right before departure any special instructions are given to those assisting the teacher, and (10) Follow up the experience of the study trip with activities. These follow-up activities are, of course, important but Walsh argues that they can

“a.) promote language development based on trip experiences, b.) reinforce conceptual learning, c.) aid in developing reading readiness and d.) reinforce practicing the social amenities."

\section{$\underline{\text { Research Projects }}$}

Research projects have traditionally been independent quests for information in the school or public library or at home (Woolever and Scott, 1988, pp. 257-258). Jarolimek and Parker in their book Social Studies in Elementary Education dropped their discussion of "reports, oral and written" after their $9^{\text {th }}$ Edition (1990, pp. 416-418): it does not appear in the $10^{\text {th }}$ Edition (1997). A type of research does show up in their later edition though. In a section on Resources for Teaching and Learning Social Studies, Jarolimek and Parker discuss the use of computers in the social studies for gathering and organizing "information needed to build and test important ideas." They argue that "electronic databases will one day include much of what is now found in 
libraries, government document centers, archives, museums, encyclopedias, and other information collections. They place enormous stacks of information at students' fingertips. Hypertext goes further. It lets children navigate and interact with those stacks, picking and choosing, creating visuals, and constructing their own software."

They also mention the possibility of creating simple charts or writing an article for the classroom newsletter based on the material found.

Issue Focused Interaction: (debate, mock trial, and panel discussions)

Alleman and Brophy (1994, p. 26) have reported that "debates were seldom reported (in their college students' memories of elementary social studies activities), but when they were, they yielded impressive patterns of outcome ratings." This author remembers a history debate from seventh grade but the only content recalled is the seating arrangement in front of the class. More typically they are probably not remembered often because they didn't happen often. None of the authors of textbooks for social studies education at the elementary level featured discussion of this activity category.

Oral Language Experience: (story-telling with pictures or puppets, writing/singing songs or conducting structured interviews)

This activity category is fairly wide ranging and it is possible that some of the specific activities are subsumed under discussions of other types of activities. Still several authors have discussed various aspects of oral language 
experience (Martorella, 1994; Hoge, 1996; Parker and Jaralimek, 1997). Walsh (1980, pp. 32-35) includes a discussion of dramatic play in which he refers to the "spontaneous, creative and free enactment of situations by children." Role playing, he distinguishes from dramatic play, in that the story "stops short of a ready made conclusion." Puppetry he believes offers an even better opportunity for effective role playing.

Performing from Scripts: (plays, puppet shows, pageants)

Although there is some discussion of play and puppetry in the various textbooks, it is not of the scripted sort: see Hoge above. Even when student performance is described as "informal dramatic play" or "formal dramatization," the activity described is role playing and not scripted performances (Katsounis, 1987, pp. 264-268). Performance from scripts is not discussed in the standard textbooks for teaching elementary social studies.

Constructing/Making: (dioramas, panoramas, shadow boxes, displays, salt/flour maps, artifacts, weaving, drying fruit, and making soup)

Out of 10 activity types Alleman and Brophy (1994) used in their study of recollections, this activity garnered $16 \%$ of the total activities reported. Of those activities reported a respectable $76 \%$ were associated with high cognitive outcomes. Even with such positive success it is not discussed in all textbooks, but it certainly is found in the literature (Parker and Jarolimek, 1997; Walsh, 1980; and Woolever and Scott, 1988). 
Art-related Activities: (painting, drawing)

While such activities are certainly popular in the elementary grades, they are not as widely discussed as instructional activities for the social studies as one might expect, which is not to say it is never discussed. The discussion by Parker and Jarolimek (1997, p. 434) might explain why many authors do not see art-related activities as social studies instructional activities. One type of creative expression they say "might be described as personal and is performed by the children because it expresses an idea or gives personal satisfaction. Having the experience is its own reward, and the child need not share such a piece of art with anyone ... .

Writing Activities: (journals, logs, letters to pen pals, letters requesting information, writing plays or dialogue)

Although "everyone" believes writing to be important, they apparently do not necessarily see it as an important instructional activity in the social studies. Still, a few authors do discuss its usefulness (Parker and Jarolimek, 1997). Martorella (1994, pp. 298-300) argues forcefully that writing is important for social studies because it is an important part of citizenship while quoting Stotsky: "Writing has been as much a part of the history of democratic self government as reading, and is essential to public speaking. In the course of American history, as local government developed, so too did the kind and amount of writing that people needed to do as citizens." 
In Social Studies and the Elementary/Middle School Student, Sunal and Haas (1993) report positive and negative memories from elementary and middle school years by pre-service and in-service elementary and middle school teachers. One would assume that some sort of behavioral conditioning would inform those teachers' choices of instructional activities. Indeed, Murray (1997) concludes in a paper on preconceptions held by pre-service secondary social studies teachers about instructional activity that “... we can no longer assume that teacher learning occurs solely through receiving new knowledge. Teachers, like other learners, interpret new content through their existing understandings and modify and interpret new ideas on the basis of what they already know or believe." Shug, Todd and Berry (1984, p. 383) argue that students want: "Group projects, field trips, independent work, less reading, discussions, clear examples, student planning, challenging learning experiences, class activities, role playing, and simulations.” Based on their review of the professional literature, Sunal and Haas (1993, p. 5) would state that this will be unattainable because "the professional literature suggests that there doesn't seem to be a match between what teachers do in social studies and what students want to do.”

There may never be a correlation however between the teachers' and students' perceptions of preferred instructional activities in the social studies classroom, but we need to realize that:

Society is characterized by increasingly rapid social and technological change ... unless children acquire 
the foundations of knowledge, attitudes, and skills in the social studies in the important elementary years, it is unlikely that teachers in the junior and senior high schools will be successful in preparing effective citizens for the $21^{\text {st }}$ century.

This was reported by the NCSS Task Force on Early Childhood/Elementary Social Studies in June of 1998 (http://www.ncss.org/standards/positions/elementary.html).

After what appeared to this author an exhaustive Internet search, the following source was typical. A curriculum overview from the Social Sciences Reference Committee of Saskatchewan had social studies content outlined and a bibliography, but there were no educational activities listed (http://www.sasked.gov.sk.ca/docs/elemsoc/adminbu/pur.html). This was also the case of the recent ERIC/chESS Digests publication list: they dealt with educational content and excluded educational activities (http://www.indiana.edu/ ssdc/digest.html). Although lists of instructional activities can be found they include rationales but exclude any type of research background.

One might assume, perhaps, this type of oversight was partly responsible for the 1994 NCSS Expectations of Excellence: Curriculum Standards for Social Studies, a statement calling for "powerful" activities and in which 96 of 141 pages are devoted to putting "Standards into Practice." In this book, many examples of instructional activities are offered. The instructional activities one 
assumes to be "powerful" but there is no research to back up the activity or to explain why the authors have chosen them. Expectations of Excellence defined these activities as having "solid content, containing various instructional approaches and active learning experiences." Carl R. Siler offers an example of a "powerful" activity in Spatial Dynamics: An Alternative Teaching Tool in the Social Studies (http://www.ncss.org/standards/positions/elementary.html). He argues that floor models and papier-mâché are the easiest way to bring interactive teaching to the classroom. Students, he argues, are no longer "bored" with the subject matter or the teacher because they are in a less repetitive environment and are being able to create with their hands.

The regular lack of stimulating experience could be why Charles Dance (1986, p. 2) believes that "the problem in elementary social studies education is that it is one of the least-liked subjects."

"Students themselves often characterize social studies as difficult, uninteresting, and largely irrelevant to their present and future lives. This comes as no surprise in light of reports that the dominant classroom pattern is characterized by lecture and recitation, reading textbooks, and completing worksheets" (http://www.ncss.org/standards/positions/elementary.html).

In summary, the literature reviewed for this study indicates that while procedures for determining or defining the social studies have changed over time, there has been very little change in the basic sources of the social studies. While new teaching areas or emphases have been introduced, they 
have, in fact, been mostly new labels for old precepts or new combinations of traditional materials.

Instructional activities are routinely not discussed in educational research. When they are offered, they are done so in sort of a how-to-do-it or recipe format. An example of this is The Social Studies Sourcebook: Ideas for Teaching in the Elementary and Middle School by Frank L. Ryan (1980). This book presents 477 instructional activities for the classroom. This is a publication filled with sample activities and rationale for their use. Ryan's book is typical. Overall, there is little documentation of the effectiveness of various social studies instructional activities beyond anecdotal information. And there is little research into which types of activity teachers prefer or their reasons for their preference. In 1991, Alleman and Brophy (p. 10) reported that, "Inspection of the third edition of the Handbook on Teaching and of recent scholarly books and journals did not yield much theory or research on." Nothing has changed. 


\section{CHAPTER 3}

Methodology

In Chapter 3 the procedure used for the study is explained. The rationale for the nature of the study's design is offered first. This is followed by a description of the population, the development of the data gathering instrument, the pilot study, and the protocol. An explanation of the scoring procedure used to summarize the data concludes the chapter.

In an interview with Anderson, Schillings, and Stahl, all now former presidents of the NCSS, McKinney-Browning in 1994 posed the question, "What is the future of primary/elementary social studies?" Anderson said, “... we have an obligation to actively promote more equitable distribution of technological resources in schools throughout the country." Stahl said, "I don't see the majority of social studies teachers moving toward increasing the use of technology and delivery systems on a day-to-day basis in the classrooms." Schillings said, "What the social studies teacher can provide is a perspective on what the students are seeing and using" (McKinney-Browning, 1994, pp. 2932). None of these individuals apparently felt that curriculum content or activities, with the notable exception of technology, was a major area for speculation.

But elsewhere there is a lot of speculation about the forthcoming century and what is coming for social studies. "In the United States, educational change is characterized by several factors, including rapid demographic shifts, 
new research into the nature of teaching and learning, and dissatisfaction with students' achievements on national tests, particularly in relation to their peers in other parts of the world. Nowhere have these changes been felt more than in the social studies curriculum" (Candis and Risinger, 1994). And this curriculum, as we have seen, has diverse disciplinary origins and history, these changes and the arguments for and against them are ongoing.

\section{$\underline{\text { Rationale }}$}

There is a great deal of information in the literature about what should be included in curriculum (Marockie, 1995; Parker and Jarolimek, 1997; NCSS http://www.ncss.org/standards/positions/elementary.html) and what methods (Hoge, 1996; Kaltsounis, 1987; Martorella, 1994) should or should not be used to teach this material. There is not a great deal of research, however, into the selection of instructional content and activities at the classroom level (Alleman and Brophy, 1991, p. 10). Because of the paucity of research available in this area an exploratory, descriptive approach seemed justified to investigate what may be happening with the classroom teacher. In view of the current interest in the new millennium it was decided to do this by investigating the professionals of the $21^{\text {st }}$ century to determine their ideas about educational activities and content in elementary social studies classes. 


\section{Population of the Study}

The population for this study included sections of undergraduate students at West Virginia University enrolled in Curriculum and Instruction 150: Elementary/Early Childhood Social Studies. These students were all preservice teachers in their final undergraduate, professional education classroom experience before beginning the culminating student teaching placement.

The rationale for using this population is twofold: (1) it is assumed that as they are about to begin their in-classroom placements they have begun to think of educational activities and content they may need and they will have been exposed to the suggestions for such activities and content from both their professors and the various textbooks, journals, and professional associations; and (2) these students will soon be in their own classrooms as professionals. It is assumed their present perceptions may tell us something about the nature of the elementary social studies class in the future.

\section{The Pilot Study}

A preliminary test of the questionnaire used in the present study was piloted, in West Virginia, at West Liberty State College in the spring of 1997. The objectives of this pilot study were: (1) to see if the questionnaire was usable as constructed, (2) to give the interviewer the feedback necessary to orchestrate the successful accomplishment of group testing with the instrument, and (3) to see if the protocol as written was appropriate. 
West Liberty State College was selected as the location for the pilot study. As a faculty member the investigator was able to use upper level sociology and social science students in his classes. In addition, an education faculty member offered the use of a Reading 210 class, a required course for elementary education majors. In an upper level Sociology 303 tutorial with only four students the questionnaire was passed out with no explanation. Based on the questions which were asked, a protocol was developed which included a brief explanation, passing out the instrument and, then, additional comments when the questionnaire was in front of the respondents. Using this protocol another upper level sociology class, Sociology 369, was tested. Here, students seemed to have no difficulties with the data-gathering instrument itself or with the oral directions, but they did complain of the difficulty and asked for permission to take the test with them. This was denied in order not to contaminate other possible respondents and because the actual data itself was not being sought from this group. All, of course, were cordially thanked, but only 12 of a class of 21 completed the forms. An explanation of why the test was so time consuming and an apology for the work involved was added to the protocol.

Finally, the group most representative of the final sample was approached. However, the cooperating professor changed her mind and said that she could not spare a class period because she was behind. She said that it could be given out in her class at the end of a lecture and she would retrieve them next time. While only seven of the class of 40 returned the forms, they 
brought them directly to the researcher. This was particularly encouraging because feedback from these pre-service teachers was that they thought the research was a good idea, they felt the time spent on the questionnaire was worth it, and they felt that it would have been worth classroom time to discuss it after the materials were turned in. This seemed to validate the protocol used. The standardized procedures in its final form follows.

\section{The Research Protocol}

The following standardized procedure was developed from the pilot study and was used in the administration of the questionnaire.

\section{Script}

Good morning (afternoon, evening). Thank you for agreeing to participate in this research study. The research goal is to study the content and instructional activities that pre-service elementary level teachers prefer when teaching social studies. The information gathered will be used for a doctoral dissertation.

I want to point out several things to you before we start:

1. Your participation is entirely voluntary and you do not have to respond to every item or question.

2. Your responses will remain anonymous and confidentiality will be maintained. 
3. Neither your class standing, athletic status, nor grades will be affected by refusing to participate in or by withdrawing from the study. Thank you for agreeing to participate in this study.

II. Hand Out Questionnaires

III. Script

1. Does anyone have a question?

2. The questionnaire is as long as it is and arranged as it is so that it can be easily compared to previously published research.

3. This is not an easy task, but once they have done the first column ranking most people find it not so difficult.

4. If you have a question as you proceed, raise your hand and I will come to you.

5. Pre-service teachers are frequently ignored in education research. Your help really is appreciated!

IV. Retrieve Questionnaires

The Data Gathering Instrument

The survey form used to collect data consists of five sheets. They

are:

1. An educational value ranking sheet of educational activities

2. An enjoyable activity ranking sheet of educational activities

3. A preferred activity ranking sheet of educational activities 
4. A most preferred/least preferred content area sheet

5. A respondent characteristic sheet

These survey instrument data collection sheets are shown in Appendix A. The first three pages of the survey instrument call for the respondent to rank 14 different educational activities. These 14 activities are the same activities previously used in the work of Alleman and Brophy (1995). Rankings were done for the criterion "educational value" by which is meant how valuable the respondent felt each activity to be as an educational experience for elementary students. Rankings were done for "enjoyable activity" by which is meant how much the respondent felt the students found the particular method to be pleasurable. Rankings were done for "preferred activity" by which is meant those methods which the respondent would prefer to use.

Respondents were asked to rank the 14 instructional activities from 114 , with one being the lowest ranking and 14 being the highest ranking. While this might seem to be a reversal of a typical ranking the procedure was followed so that the resultant data could be more easily compared with the previous study by Alleman and Brophy (1995).

Each of the areas for rankings were further subdivided: for each criteria pre-service elementary teachers were asked to decide whether they thought grade level would cause changes in their rankings. For this distinction, Grades K-3, Grades 4-6, and Grades 7-8 were assigned. 
The fourth page of the questionnaire was to look for the five most preferred and five least preferred elementary social studies content areas. The 25 possible areas were derived from the work of Murray (1998). On this, too, respondents were asked if grade level might affect their choices. For this distinction, Grades K-3, Grades 4-6, and Grades 7-8 were again assigned.

Page five of this survey focuses on the demographic variables. Here, four variables were examined. They were age, sex, grade point average, and student classification.

\section{Procedure Used in the Analysis of Data}

Research Question 1: What social studies instructional activities do preservice elementary teachers perceive as having the most educational value for teaching at the various elementary grades?

Research Question 2: What social studies instructional activities do preservice elementary teachers perceive as providing the most enjoyment for students in the elementary grades?

Research Question 3: What social studies instructional activities do preservice elementary teachers prefer to use at the various elementary grades?

The data to answer research questions 1, 2, and 3 was obtained on the first, second, and third page respectively of the questionnaire. For each grade cluster column the data needed to tabulate overall rankings was obtained by multiplying the total number of respondents assigning a specific rank by the point value for that rank to obtain a weighted response for that population. 
Since one has the least perceived educational value and rank of 14 the highest, the higher the product the greater the ranking of the particular instructional activity for the criteria being ranked. Rankings from the entire respondent population for the different grade clusters for each of the three criteria may then be compared. (See Tables 1-15 in Appendix B.)

Research Question 4: What do pre-service elementary teachers select as most preferred social studies curriculum content areas to present at the various elementary grades?

The data to answer this question was obtained from the fourth page of the questionnaire. The procedure to manipulate the data was the preferred content area were determined by adding all the most preferred top five rankings for a particular content area together and determining top choices. Similarly, least preferred content areas were determined by taking all rankings of the five least preferred content areas and adding them to determine the bottom five choices. (See Tables 16-20 in Appendix B.)

The tables in Appendix B are intended to show the reader the working tabulations by which conclusions were derived. For example, Tables $1,2,3 ; 5$, 6, 7; and 9, 10,11 show the weighted responses explained above. While it should be obvious that rankings derived from such weighted responses are not equidistant, it may be of interest to some to see the relative weights. Similarly, Tables 16, 17, and 18 show the tallies on which the most and least preferred rankings for instructional content are based. 
The derived rankings for the various instructional content areas and for the instructional activities will be presented in Chapter 4: Presentation of the Data. 


\section{CHAPTER 4}

\section{Presentation of the Data}

Chapter 4 provides an analysis and presentation of the data. The chapter is organized around the four research questions presented earlier. The findings are presented as they relate to each of these questions.

The procedure used to analyze the data gathered with the questionnaires was different for the instructional activities and for the instructional content. Pre-service elementary teachers were asked to rank social studies instructional activities according to educational value, perceived student enjoyment, and personal preference for Grades K-3, Grades 4-6, and for Grades 7 and 8. These nine categories were tabulated by multiplying the ranking given (one through 14) by the total number of questionnaire respondents giving that particular ranking. For example, on Table 1 in Appendix B the weighted responses were then ranked from the lowest rank of one for the lowest score of 433 to the highest rank of 14 for the highest score of 841 for educational value to students in Grades K-3.

For instructional content the procedure used was to count the frequencies of response for the most favored items chosen and the least favored items chosen. While respondents were asked to rank their five most and least favored items, this was to add variety to the questionnaire and make it somewhat less time consuming. For tabulation purposes responses are treated as most and least popular. Total tallies were then ranked to determine what 
the five highest ranked educational content areas preferred by respondents were and also what the five lowest ranked educational content areas indicated by respondents were.

The four population variables (Age, Sex, Grade Point Average, and Class) were tallied. While they empirically verify what is already intuitively known about the student characteristics that make up the enrollment of the Curriculum and Instruction 150: Elementary/Early Childhood Social Studies at West Virginia University, they are presented below.

The questionnaire used as the data gathering instrument is presented in Appendix A. The items on the first three pages dealing with instructional activities were arranged to follow the order of items used by Alleman and Brophy in their test of in-service teachers (Brophy and Alleman, 1995). Further, the order of ranking from one as lowest to 14 as highest ranking was also used so as to follow the lead of Alleman and Brophy and allow for comparison. The sequencing of the fourth page dealing with instructional content was arranged so as to follow the order of items used by Murray in his test of pre-service teachers (Murray, 1998). This, too, was done to allow for duplicating a research but on a different population.

The findings from each section of the questionnaire are organized into tables and presented in Appendix B as they relate to each of the four research questions. 
Research Question 1: What social studies instructional activities do pre-service elementary teachers perceive as having the most educational value for teaching at the various elementary grades?

Figure 1 compares the derived rankings from the respondent population for the various instructional activities for each of the three combined elementary grade levels: Grades K-3, Grades 4-6, and Grades 7-8. The five instructional activities highest ranked for educational value and the five lowest ranked educational values are presented for each elementary grade cluster. The activities seen as having higher educational values are: Oral language experience chosen for Grades K-3 and Grades 4-6; field trips were seen as having high value for all three grade clusters; performing from scripts was highly ranked for Grades K-3 (but is seen as of little value for Grades 7-8); using games and simulations and, also, constructing/making activities were seen as having high educational value for Grades K-3 and Grades 4-6 but not Grades 7-8. Reinforcing activities: class discussion was ranked in the top five for Grades 4-6 and Grades 7-8. While reinforcing activities: seatwork was ranked among the bottom five choices for educational value for all three grade clusters. Writing activities were seen as educationally of value starting with Grades 4-6 and into Grades 7-8. Issue focused interaction was considered similarly to writing activities for these later grades but was not seen as having great educational value for Grades

K-3. Research projects were given high rankings for Grades 7-8 even though they were specifically rejected for the primary grades. Other activities ranked 
Figure 1. What Social Studies Instructional Activities Do Pre-service Elementary Teachers Perceive as Having the Most Educational Value for Teaching at the Various Elementary Grades?

\begin{tabular}{|c|c|c|c|c|c|}
\hline \multicolumn{2}{|c|}{ GRADES K-3 } & \multicolumn{2}{|c|}{ GRADES 4-6 } & \multicolumn{2}{|c|}{ GRADES 7-8 } \\
\hline Highest Ranked & Lowest Ranked & Highest Ranked & Lowest Ranked & Highest Ranked & Lowest Ranked \\
\hline $\begin{array}{l}\text { Oral language } \\
\text { experience } \\
\text { (story-telling with } \\
\text { pictures or puppets, } \\
\text { writing/singing songs, } \\
\text { or conducting } \\
\text { structured interviews) }\end{array}$ & $\begin{array}{l}\text { Reading and } \\
\text { discussing the text } \\
\text { Reinforcing activities: } \\
\text { seatwork (crossword } \\
\text { puzzles, fill-in-the- } \\
\text { blank, matching, } \\
\text { locating and coloring } \\
\text { correct answers, } \\
\text { vocabulary and skill } \\
\text { reinforcement) } \\
\text { Research project } \\
\text { Issue focused } \\
\text { interaction } \\
\text { (debate, mock trial, } \\
\text { panel discussions) } \\
\text { Listening to tapes, } \\
\text { lectures, or dramatic } \\
\text { readings by the } \\
\text { teacher or resource } \\
\text { person }\end{array}$ & $\begin{array}{l}\text { Field trips } \\
\text { Reinforcing activities: } \\
\text { class discussion (open- } \\
\text { ended questions, } \\
\text { reading and interpreting } \\
\text { a map, graph, cartoon, } \\
\text { or paragraph) } \\
\text { Oral language } \\
\text { experience } \\
\text { (story-telling with } \\
\text { pictures or puppets, } \\
\text { writing/singing songs, } \\
\text { or conducting } \\
\text { structured interviews) } \\
\\
\text { Writing activities } \\
\text { (journals, logs, letters } \\
\text { to pen pals, letters } \\
\text { requesting information, } \\
\text { writing plays or } \\
\text { dialogue) } \\
\text { Issue focused } \\
\text { interaction } \\
\text { (debate, mock trial, } \\
\text { panel discussions) }\end{array}$ & $\begin{array}{l}\text { Reinforcing activities: } \\
\text { seatwork (crossword } \\
\text { puzzles, fill-in-the- } \\
\text { blank, matching, } \\
\text { locating and coloring } \\
\text { correct answers, } \\
\text { vocabulary and skill } \\
\text { reinforcement) } \\
\text { Art-related activities } \\
\text { (painting, drawing) } \\
\text { Listening to tapes, } \\
\text { lectures, or dramatic } \\
\text { readings by the } \\
\text { teacher or resource } \\
\text { person } \\
\text { Reading and } \\
\text { discussing text }\end{array}$ & $\begin{array}{l}\text { Field trips } \\
\text { Reinforcing activities: } \\
\text { class discussion (open- } \\
\text { ended questions, } \\
\text { reading and interpreting } \\
\text { a map, graph, cartoon, } \\
\text { or paragraph) } \\
\text { Research project } \\
\text { Issue focused } \\
\text { interaction } \\
\text { (debate, mock trial, } \\
\text { panel discussions) } \\
\text { Writing activities } \\
\text { (journals, logs, letters } \\
\text { to pen pals, letters } \\
\text { requesting information, } \\
\text { writing plays or } \\
\text { dialogue) }\end{array}$ & $\begin{array}{l}\text { Reinforcing activities: } \\
\text { seatwork (crossword } \\
\text { puzzles, fill-in-the- } \\
\text { blank, matching, } \\
\text { locating and coloring } \\
\text { correct answers, } \\
\text { vocabulary and skill } \\
\text { reinforcement) } \\
\text { Art-related activities } \\
\text { (painting, drawing) } \\
\text { Viewing slides, } \\
\text { filmstrips, movies, or } \\
\text { videos } \\
\text { Listening to tapes, } \\
\text { lectures, or dramatic } \\
\text { readings by the } \\
\text { teacher or source } \\
\text { person } \\
\text { Performing from } \\
\text { scripts } \\
\text { (plays, puppet shows, } \\
\text { pageants) }\end{array}$ \\
\hline
\end{tabular}


Research Question 2: What social studies instructional activities do preservice elementary teachers perceive as providing the most enjoyment for students in the various elementary grades?

Figure 2 compares the derived ranking from the respondent population in terms of perceived enjoyment for the various instructional activities for each of the three combined elementary grade levels: Grades K-3, Grades 4-6, and Grades 7-8. The five highest ranked instructional activities for perceived student enjoyment and the five ranked lowest for perceived enjoyment for each elementary grade cluster are presented.

Activities perceived by pre-service teachers as providing greatest enjoyment for students were: Field trips at all three grade clusters, and artrelated activities at all three grade clusters. Construction/making activities was seen as enjoyable for the earlier grades: Grades K-3 and Grades 4-6, as was performing from scripts. Oral language experience was not perceived as providing enjoyment after Grades K-3. Using games and simulations were not ranked highly for those primary grades but were seen as highly enjoyed by students beyond at the Grades 4-6 and Grades 7-8 clusters. In Grades 7-8, issue focused interaction, which was seen as not enjoyable for Grades K-3 was highly ranked. Also highly ranked at Grades 7-8 was viewing slides, filmstrips, movies, or videos. Ranked least for enjoyment for all three grade clusters were: reading and discussing the text, research projects, and both reinforcing activities: seatwork and class discussion. Ranked low for perceived 
student enjoyment was listening to tapes, lectures, etc. for both Grades 4-6 and Grades 7-8. 
Figure 2. What Social Studies Instructional Activities Do Pre-service Elementary Teachers Perceive as Providing the Most Enjoyment for Students in the Various Elementary Grades?

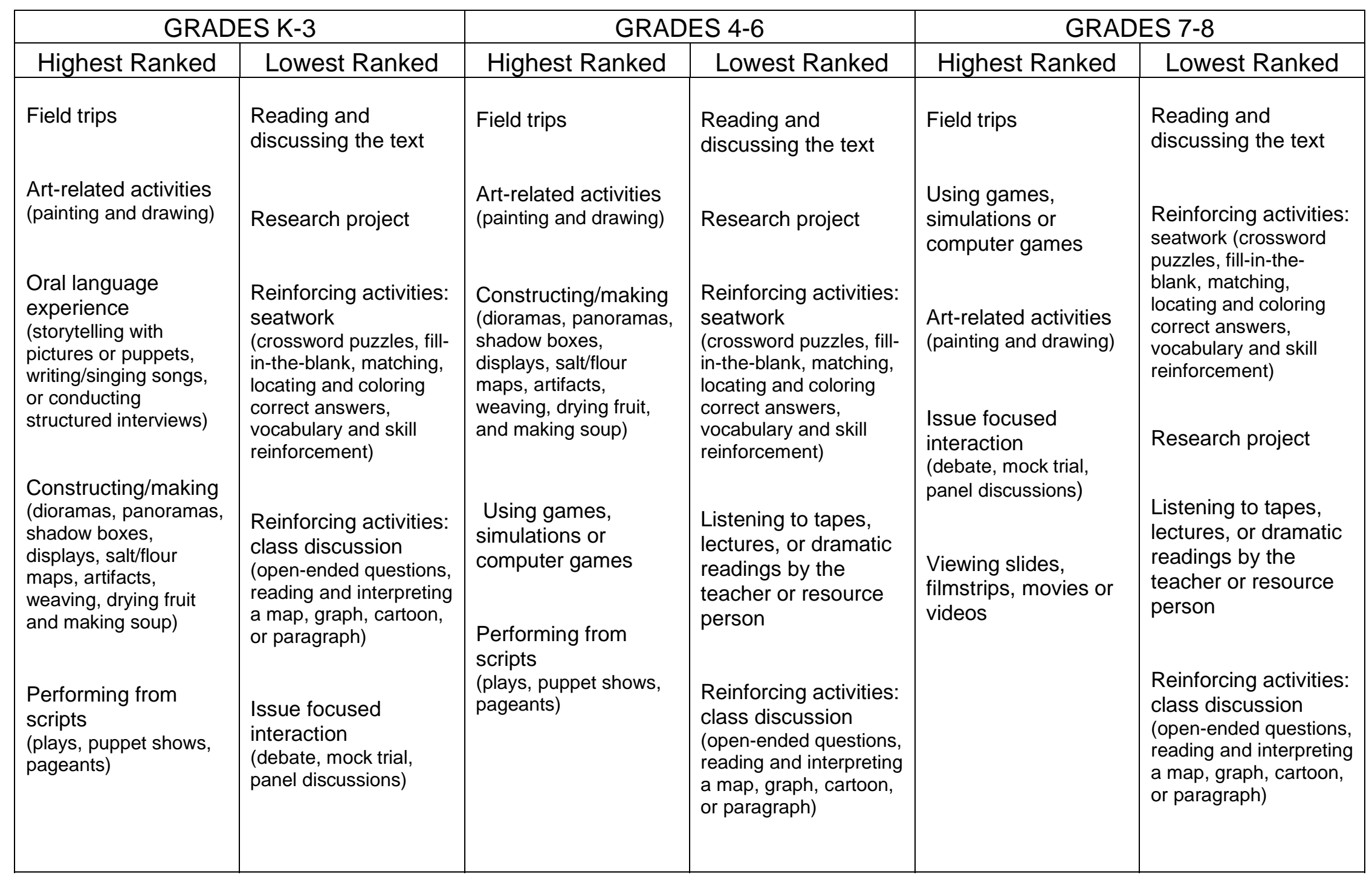


Research Question 3: What social studies instructional activities do preservice elementary teachers prefer to use at the various elementary grades?

Figure 3 compares the derived rankings from the respondent population for the various instructional activities for each of the combined elementary grade levels: Grades K-3, Grades 4-6, and Grades 7-8, respectively for teacher preference. The five highest ranked instructional activities for preference and the five ranked lowest for pre-service elementary teachers preference for each elementary grade cluster are presented.

Respondents' highest rankings for preferred instructional activities for their classroom use included both field trips and reinforcement activities: class discussion for all three grade clusters. Two of the most preferred activities for Grades K-3, art-related activities and oral language experience (also chosen for Grades 4-6), were ranked as least preferred for Grades 7-8.

Using games and simulations and performing from scripts were both preferred instructional activities, but only in the primary classrooms. Writing activities and issue-focused interaction (which was specifically not preferred for Grades K-3) were both highly ranked as a preference for activity in Grades 4-6 and Grades 7-8.

Research projects were also ranked highly for preferred classroom use by these pre-service teachers even though they ranked research projects as least preferred for Grades K-3 and Grades 4-6. Reinforcing activities: seatwork was one of the least preferred activities for each of the three grade clusters, as was listening to tapes, lectures, or dramatic readings. Additionally, viewing slides, 
filmstrips, movies, or videos was ranked as least preferred for use in Grades 4-6 and construction/making activities were least preferred for use in Grades 7- 8.

A comparative summary of the various rankings of data in response to Research Questions 1, 2, and 3 are presented in Appendix B: Tables 13 through 15.

Research Question 4: What do pre-service elementary social studies teachers say are the most preferred social studies curriculum content areas to present at the various elementary grades?

A summary of data is presented below in Figure 4. Figure 4 presents the five most preferred and five least preferred of the social studies content areas for the elementary grade clusters based on actual tally and derived ranking as described in Chapter 3. Those social studies content areas ranked highest by pre-service teachers for Grades K-3 were multicultural education, current events, drug education, conflict resolution, and also values education. The social studies content areas ranked as least preferred for Grades K-3 were: (21) Archeology, (22) Anthropology, (23) Philosophy, (24) Law-related education, and (25) Religion.

Those social studies content areas ranked highest by pre-service teachers for Grades 4-6 were: (1) Current events, (2) Drug education, (3) Multicultural education, (4) State history, and (5) U. S. history. The social studies content areas ranked as least preferred for Grades 4-6 were: (21) Economics, (22) Law-related education, (23) Political science, (24) Philosophy, and (25) Religion. 
Figure 3. What Social Studies Instructional Activities Do Pre-service Elementary Teachers Prefer to Use at the Various Elementary Grades?

\begin{tabular}{|c|c|c|c|c|c|}
\hline \multicolumn{2}{|c|}{ GRADES K-3 } & \multicolumn{2}{|c|}{ GRADES 4-6 } & \multicolumn{2}{|c|}{ GRADES 7-8 } \\
\hline Highest Ranked & Lowest Ranked & Highest Ranked & Lowest Ranked & Highest Ranked & Lowest Ranked \\
\hline $\begin{array}{l}\text { Reinforcing activities: } \\
\text { class discussion } \\
\text { (open-ended questions, } \\
\text { reading and interpreting } \\
\text { a map, graph, cartoon, } \\
\text { or paragraph) } \\
\text { Performing from } \\
\text { scripts } \\
\text { (plays, puppet shows, } \\
\text { pageants) }\end{array}$ & $\begin{array}{l}\text { Reading and } \\
\text { discussing the text } \\
\text { Reinforcing activities: } \\
\text { seatwork } \\
\text { (crossword puzzles, fill- } \\
\text { in-the-blank, matching, } \\
\text { locating and coloring } \\
\text { correct answers, } \\
\text { vocabulary and skill } \\
\text { reinforcement) } \\
\text { Issue focused } \\
\text { interaction } \\
\text { (debate, mock trial, } \\
\text { panel discussions) } \\
\\
\text { Listening to tapes, } \\
\text { lectures, or dramatic } \\
\text { readings by the } \\
\text { teacher or resource } \\
\text { person }\end{array}$ & $\begin{array}{l}\text { Writing activities } \\
\text { (journals, logs, letters } \\
\text { to pen pals, letters } \\
\text { requesting information, } \\
\text { writing plays or } \\
\text { dialogue) } \\
\text { Oral language } \\
\text { experience } \\
\text { (story-telling with } \\
\text { pictures or puppets, } \\
\text { writing/singing songs, } \\
\text { or conducting } \\
\text { structured interviews) } \\
\text { Reinforcing activities: } \\
\text { class discussion } \\
\text { (open-ended questions, } \\
\text { reading and interpreting } \\
\text { a map, graph, cartoon, } \\
\text { or paragraph) }\end{array}$ & $\begin{array}{l}\text { Reinforcing activities: } \\
\text { seatwork } \\
\text { (crossword puzzles, fill- } \\
\text { in-the-blank, matching, } \\
\text { locating and coloring } \\
\text { correct answers, } \\
\text { vocabulary and skill } \\
\text { reinforcement) } \\
\text { Listening to tapes, } \\
\text { lectures, or dramatic } \\
\text { readings by the } \\
\text { teacher or resource } \\
\text { person }\end{array}$ & $\begin{array}{l}\text { Issue focused } \\
\text { interaction } \\
\text { (debate, mock trial, } \\
\text { panel discussions) } \\
\text { Writing activities } \\
\text { (journals, logs, letters } \\
\text { to pen pals, letters } \\
\text { requesting information, } \\
\text { writing plays or } \\
\text { dialogue) } \\
\text { Field trips } \\
\text { Reinforcing activities: } \\
\text { class discussion } \\
\text { (open-ended questions, } \\
\text { reading and interpreting } \\
\text { a map, graph, cartoon, } \\
\text { or paragraph) } \\
\text { Research project }\end{array}$ & $\begin{array}{l}\text { Reinforcing activities: } \\
\text { seatwork (crossword } \\
\text { puzzles, fill-in-the- } \\
\text { blank, matching, } \\
\text { locating and coloring } \\
\text { correct answers, } \\
\text { vocabulary and skill } \\
\text { reinforcement) } \\
\text { Art-related activities } \\
\text { (painting, drawing) } \\
\text { Listening to tapes, } \\
\text { lectures, or dramatic } \\
\text { readings by the } \\
\text { teacher or resource } \\
\text { person } \\
\text { Constructing/making } \\
\text { (dioramas, panoramas, } \\
\text { shadow boxes, } \\
\text { displays, salt/flour } \\
\text { maps, artifacts, } \\
\text { weaving, drying fruit } \\
\text { and making soup) } \\
\text { Oral language } \\
\text { experience } \\
\text { (story-telling with } \\
\text { pictures or puppets, } \\
\text { writing/singing songs, } \\
\text { or conducting } \\
\text { structured interviews) }\end{array}$ \\
\hline
\end{tabular}


Figure 4. The Five Highest (Top) Ranked Instructional Content Areas and the Five Lowest (Bottom) for the Various Elementary Grade Clusters

$\begin{array}{lll}\begin{array}{lll}\text { GRADES K-3 } \\ \begin{array}{l}\text { Multicultural } \\ \text { Education }\end{array}\end{array} & \text { GRADES 4-6 } & \text { GRADES 7-8 } \\ \text { Current Events } & \text { Drug Education } & \text { Current Events } \\ \text { Drug Education } & \begin{array}{c}\text { Multicultural } \\ \text { Education }\end{array} & \text { Career Education } \\ \begin{array}{l}\text { Conflict Resolution/ } \\ \text { Value Education }\end{array} & \text { State History } & \begin{array}{c}\text { Multicultural } \\ \text { Education }\end{array} \\ & \text { U. S. History } & \text { U. S. History }\end{array}$

\begin{tabular}{lll}
\hline GRADES K-3 & GRADES 4-6 & GRADES 7-8 \\
Religion & Religion & Religion \\
Law-related Education & Philosophy & Law-related Education \\
Philosophy & Political Science & Philosophy \\
Anthropology & Law-related Education & Political Science \\
Archeology & Economics & Archeology
\end{tabular}


Those social studies content areas ranked highest by pre-service teachers for Grades 7-8 were: (1) Current events, (2) Drug education, (3) Career education, (4) Law-related education, and (5) U. S. history. Those social studies areas ranked as least preferred for Grades 7-8 were: (21) Archeology, (22) Political science, (23) Philosophy, (24) Law-related education, and (25) Religion.

\section{$\underline{\text { Population Variables }}$}

Figure 5 shows the tally for respondent characteristics of age, sex, grade point average, and student classification. The results are what one might intuitively use to describe university students who are about to begin the student teaching sequence in elementary education. With a grade range of 2.54.0, most (48\%) of the respondents reported a B average. All of the prospective student teachers were seniors or in their fifth year of study. They were typically $(79 \%)$ college age of $18-22$. Although, if the fifth year is allowed to influence the age category by pushing college age into the next category which begins at 23 , then as many as $95 \%$ of respondents may be traditional students. There is also data to back the stereotype of the female elementary teacher: fully $86 \%$ of respondents for this study were women. We can apparently feel comfortable with the respondent population.

In summary, 80 pre-service elementary education majors at West Virginia University were asked their opinions about appropriate content and activities for social studies. These students were mostly traditional college age 
females with typical grades in their final sequence of classes before beginning their student teaching experience. These respondents ranked 14 instructional activities as to their educational value, perceived student enjoyment and personal preference; they ranked 25 instructional content areas for the five most and least preferred. Chapter 5 attempts to articulate these differences and explain them. 
Figure 5. Descriptive Population Variables of Respondents

1. Age

$\underline{63} 18-22$

13 23-27

$\underline{2} 28-32$

$\underline{2} 32$ and above
2. Sex

11 Male

$\underline{69}$ Female $\underline{18} \quad 2.5-2.99$

$\underline{38} \quad 3.0-3.49$

$24 \quad 3.5-4.0$

3. Grade Point Average

$\underline{0}$ below 2.0

은 $\quad 2.0-2.49$

4. Classification

0 Freshman

o Sophomore

0 Junior

$\underline{38}$ Senior

$\underline{42}$ Fifth Year 


\section{CHAPTER 5}

Summary, Conclusions, and Implications

The overall objective of this study is to describe the stated perceptions of pre-service elementary educators concerning instructional activities and instructional content.

Four research questions were developed to guide the study.

1. What social studies instructional activities do pre-service elementary teachers perceive as having the most educational value for teaching the various elementary grades?

2. What social studies instructional activities do pre-service elementary teachers perceive as providing the most enjoyment for students in the various elementary grades?

3. What social studies instructional activities do pre-service elementary teachers prefer to use at the various elementary grades?

4. What do pre-service elementary teachers say are the most preferred social studies curriculum content areas to present at the various elementary grades?

The population surveyed was the population of pre-service elementary social studies teachers at West Virginia University. No attempt was made to find their areas of residence, for while West Virginia University is a regional university that draws both national and international students, these 
respondents could hardly be said to be representative in any significant way of their home regions.

\section{Summary of Major Findings}

The major findings of this study are discussed in this section. Since the investigation looks at opinion and is not set up in such a way as to obtain one "winning" instructional activity or one "winning" content area, the emphasis here will be on those typical responses that appear most frequently on the data. Thus, predominant patterns will be shown and discussed.

Several patterns emerge from the data. The most striking involves field trips. For all elementary grade levels, field trips are essentially seen as having the highest educational value, perceived as being the most enjoyed by students, and are preferred most by the respondents. No other instructional activity was given such a high ranking.

As shown in Chapter 2, this affinity is also true of those who tell the teachers how to teach or the authors of college textbooks of elementary social studies education (Walsh, 1980; Kaltsounis, 1987; Hoge, 1996; Parker and Jarolimek, 1997; Martorella, 1994; and Woolever and Scott, 1988).

Woolever and Scott (p. 227) state "those in the early grades are most in need of 'active' learning experiences." Perhaps, there is no better example of active learning than a field trip. Field trips also aid in the development of, at least, three of the thinking skills, essential to social studies (decision making skills would probably not routinely be included). 
These skills are described in The Essentials Statement (1980), a pamphlet that is distributed by the National Council for the Social Studies. The various instructional activities are listed here:

*Data Gathering Skill. Learning to:

Acquire information by observation

Locate information from a variety of sources

Compile, organize, and evaluate information

Extract and interpret information Communicate orally and in writing

*Intellectual Skills. Learning to:

Compare things, ideas, events and situations on the basis of similarities and differences Classify or group items in categories Ask appropriate and searching questions Draw conclusions or inferences from evidence

Arrive at general ideas

Make sensible predictions from generalizations 
*Decision Making Skills. Learning to:

Consider alternative solutions

Consider the consequences of each solution

Make decisions and justify them in relationship to democratic principles

Act, based on the decision

*Interpersonal Skills. Learning to:

See things from the point of view of others

Understand one's own beliefs, feelings, abilities, and shortcomings and how they affect relations with others Use group generalizations without stereotyping and arbitrarily classifying individuals

Recognize value in individuals different from one's self and groups different from one's own Work effectively with others as a group member 
Give and receive constructive criticism

Accept responsibility and respect the

right and property of others

Instructional activities with highest rankings for preferred use on the part of respondents for Kindergarten through Grade 3 were: (1) field trips, (2) oral language experiences, (3) art-related activities, (4) using games, and (5) reinforcing activities: discussion. Instructional activities with highest rankings for preferred by respondents for Grades 4 through 6 were:

(1) field trips, (2) writing activities, (3) oral language experiences, (4) class discussion, and (5) issue focused interaction. Here for preferred use respondents ranked activities differently for the different grade levels. Generally, a steady increase (or decrease) from lower grades to upper grades is shown with progressions particularly pronounced in the step to the Grades 7-8 cluster. While there appears to be no common denominator to those highly preferred instructional activities, in fact, the six top ranked preferred instructional activities for Kindergarten through Grade 3 are also the top six ranked activities with most perceived educational value (although in a different order). Using the top six ranked preferred activities seems appropriate since there were two activities tied for fifth rank. This top six in pre-service teacher preferred activity also matched the respondents top six ranked instructional activities for educational value, educator preferred activity, and perceived student enjoyment were the same for Kindergarten through Grade 3. 
Presumably, respondents felt that their students in Grades K-3 would receive greater educational value out of educational activities that they enjoy, and so they would prefer to use them. If so, this rationale did not obtain for the higher grade clusters. Although for Grades 4-6 and Grades 7-8, the most preferred instructional activities were the same as the most perceived to have the high educational value, there was no relationship to the activities ranked highly for student enjoyment.

All of the preferred instructional activities, as classified by this author, are examples of active learning. Additionally, most of them allow skill development in at least two and some development in all four of the skills identified above as appropriate to the social studies. Figure 6 lists the highest ranked instructional activities and suggestions of what would be the most likely skill(s) associated with them. Figure 6 contrasts strongly with Figure 7 below, which lists the lowest ranked instructional activities for the various grade clusters with the skills which this author believed to be most closely associated with them.

Reinforcing activities or seatwork (crossword puzzles, fill-in-the-blank, matching, locating and coloring correct answers, vocabulary, and skill reinforcement) were consistently ranked low for educational value, student enjoyment, and educator preference by the respondents for this study. This was also the consensus of the in-service teachers in the Murray study (1998) and by the in-service teachers in the Alleman and Brophy study (1995). Additionally, Alleman and Brophy (1994) citing college students' memories of 
instructional activities and learning outcomes have concluded seatwork was not worthwhile since no learning outcomes were remembered. Although a couple of authors of college textbooks on elementary social studies education (Hoge, 1996; Parker and Jarolimek, 1997) have argued these types of reinforcing activities for vocabulary development, most (Hoge, 1996;

Kaltsounis, 1987; Martorella, 1994; Sunal and Haas, 1993) do not include it in their discussion of instructional activities.

Thornton in the 1991 Handbook of Research in Social Studies (p. 10) reviewed the literature to conclude that seatwork of quality, appropriate difficulty, varied, clearly understood, and well-monitored all were predictors of students' task engagement rates. He also said, "These practices are frequently not followed." Even if they were, being on task does not necessarily correlate with high educational outcomes. Although, one might argue that staying on task would negate the idea of a boring activity which should cause increased learning. Nevertheless, seatwork is the negative correlate of the positive field work experience. Seatwork is not active, it appears to be mostly not effective and at best, it fosters one learning skill, e.g., data gathering. 
Figure 6. Highest Ranked Instructional Activities for Teacher Preference and Associated Skill(s)

Field Trips

Oral Language Experience

(story-telling with pictures or puppets, writing/singing songs, or conducting structured interviews)

Reinforcing Activities:

class discussion

(open-ended questions, reading and interpreting a map, graph, cartoon or paragraph)

Performing from Scripts

(plays, puppet shows, pageants)

Using Games, Simulations, or Computer Games

Constructing/Making (dioramas, panoramas, shadow boxes, displays, salt/flour maps, artifacts, weaving and drying)

Research Project

Writing Activities

(journals, logs, letters to pen pals, letters requesting information, writing plays or dialogue)

Issue Focused Interaction

(debate, mock trial, panel discussions)
Data Gathering Skills Intellectual Skills Interpersonal Skills

Intellectual Skills Interpersonal Skills Decision Making Skills

Intellectual Skills

Data Gathering Skills Interpersonal Skills

Data Gathering Skills Intellectual Skills

Data Gathering Skills Interpersonal Skills Intellectual Skills

Data Gathering Skills Intellectual Skills Decision Making Skills

Data Gathering Skills Intellectual Skills Decision Making Skills Interpersonal Skills

Data Gathering Skills Intellectual Skills Interpersonal Skills Decision Making Skills 
Figure 7. Lowest Ranked Instructional Activities for Teacher Preference and Associated Skill(s)

Reading and Discussing the Text

Reinforcing Activities: seatwork (crossword puzzles, fill-in-the-blank, matching, locating and coloring correct answers, vocabulary and skill reinforcement)

Art-Related Activities (painting, drawing)

Research Projects

Listening to Tapes, Lectures or Dramatic Readings by the

Teacher or Resource Person

Issue Focused Interaction

(debate, mock trial, panel discussions)

Viewing Slides, Filmstrips, Movies or Videos

Performing from Scripts (plays, puppet shows, pageants)
Data Gathering Skills

Data Gathering Skills
Data Gathering Skills

Data Gathering Skills

For Grades K-3

Data Gathering Skills

Data Gathering Skills

Data Gathering Skills 
It is interesting to note that the learning activities least favored for their classroom use by these pre-service teachers were those most easily graded and least disruptive.

Indeed, Nelson (1991) has argued that teachers "often design classes to control students." In terms of grading students, the learning activities most frequently chosen as preferred for classroom and having high educational value are those activities which most lend themselves to portfolio development. Suggested materials for inclusion in student portfolios (Grady, 1992, pp. 21-23) include writing samples including songs, letters, and plays; copies of research projects; outcomes of game use; quotes showing awareness from class activities; including field trips; pictures of constructions; and even, art projects. Although in this author's view in the social studies these usually aren't creative or student generated. Portfolio assessment is best when students are in charge of what goes into their portfolios. The most obvious benefit is that "the contents of the portfolio are actual pieces of student work, not approximations supplied by a score on a standardized test" (Grady, 1992, p. 12).

In their rankings these pre-service social studies teachers made distinctions on the basis of grade (or age), but these were mostly in the upper grades where they saw less student interest in such things as performance activities and construction activities. They were consistent, however, in their perception that students enjoy educational activities where they are involved the most (or at least teacher direction is at a minimum, as in viewing activities). 
Overall, the pattern for the respondents shows a preference to use what they think has greater educational value than what they perceive their students would enjoy. Except in the earliest grades where they seem to prefer to use activities that, by their ranking and those ranking categories for perceived enjoyment and educational value, are in congruence.

Murray's work with in-service social studies teachers (Murray, 1997) does not show as much relationship between teacher's preference and perceived educational value. Two instances where such relationships exist and which this study duplicated were class discussion and listening, which both scored high for perceived educational value and educator preference and seatwork and writing activities, which both ranked low for perceived educational value and educator preference. Murray used 14 activities in his work, his highest rankings were one, not 14, which necessitates reversing respondents numbers for comparisons. Further, he did not include these activities: oral language experience, constructing/making activities, or artrelated activities. He did include taking notes, demonstrations followed by activity, and small group activities. Although his last two activities could subsume, presumably, the two activities used in this study, no attempt was made to relate the data for these varying activity categories.

Alleman and Brophy have done similar work with in-service teachers enrolled in graduate social studies education classes. Although they derive their rankings to a half-point for ties (the average of the two rankings) and this study gives the higher ranking to both of the tied ranks and drops the next 
rank, their data may be used for comparison to the current study. (See Table 23 in Appendix B.)

In the Alleman and Brophy study, the top five ranked instructional activities preferred by in-service social studies teachers were the same (although not necessarily the same order of ranking) as the five highest ranked instructional activities in terms of educational value. These changed only slightly for the different grade clusters. These top five rankings for educational value and preferred use of in-service teachers in the Alleman and Brophy study Kindergarten through Grade 3 were: class discussion, viewing slides, etc., field trips, issue focused interaction, oral language experience, and writing activities. Highest rankings for educational activities for that study for Grades 4 through 6 were: class discussion, field trips, issue focused interaction, oral language experiences, and writing activities. Top ranked educational activities for Grades 7 and 8 in the Alleman and Brophy study were: class discussion, field trips, issue focused interaction, oral language experiences, and writing activities.

Here every highly ranked instructional activity for educational value was also ranked highly preferred by the respondents. These in-service teachers, except for viewing slides instead of issue focused interaction, for the earliest grade cluster chose the same instructional activities for all grade clusters. The present study with pre-service teachers shows the same predilection for preferring what is seen as being of most educational value, but shows a discernment for what appears to be more grade relevant activities. Of 
14 instructional activities for ranking, Alleman and Brophy respondents chose a total of six, on the present study with pre-service social studies teachers respondents chose a total of 10 with only one activity (field trips) being chosen for all grade clusters.

The data concerning most preferred and least preferred content areas would appear to be straightforward. Here pre-service elementary teachers most preferred current events, drug education, and multicultural education for all three grade clusters. Respondents ranked U. S. history as a top five ranking for Grades 4-6 and Grades 7 and 8. They felt that conflict resolution and values education was very important for Kindergarten through Grade 3 and ranked state history as a top five preference for Grades 4 through 6. Career education was a top five choice for Grades 7 and 8.

The pre-service teacher respondents least preferred philosophy, religion, and law-related education, which is a component of civics at those grade levels. Other lowest ranked instructional content areas for Kindergarten through Grade 3 were anthropology and archeology. Other least preferred content areas for Grades 4 through Grade 6 were economics and political science. Archeology and political science also ranked among the bottom five preferred content areas for the social studies in Grades 7 and 8. This finding raises some questions about how students are defining the content areas since political science, too, is a component of what is generally called civics, but which was not available as a content area of choice. Murray (1998) has looked at preferred content areas of pre-service education majors. While the content 
area list was the same in his study as the present one, the results are to some extent non-comparable. This is because he divides the grade clusters into Kindergarten through Grade 2, Grades 3 and 4, and Grades 5 and 6. Further, his rankings go from one to five for least to most preferred with each content area being ranked. Nonetheless, it is interesting to note that across his grade clusters, least preferred content areas were anthropology, archeology, humanities, and law-related education and political science. Since these were found among the lowest ranked content areas in the present study, one again wonders how respondents are defining law-related and political science objectives. The five most highly ranked instructional content areas across the Murray grade clusters were geography, sociology, values education, conflict resolution, and multicultural education. Of these only multicultural education was ranked in the top five as preferred content area in the present study.

No attempt was made within this study to ascertain the reasons for respondents' choices: if in fact they can be known. But, since the study population was, in fact, also a student population one hypothesis might be that they had been influenced by the West Virginia Social Studies Goals and Objectives (Marockie, 1995). Since West Virginia was the state in which they studied and, presumably, a majority would begin their careers as educators, it seemed appropriate to see if there were noticeable or obvious similarities between respondents' choices and West Virginia's official preferences of social studies content areas for the elementary grades. Consequently, those pertinent West Virginia standards were tallied by this researcher as to appropriate 
content area description for the various objectives. (For standards and tallies see Tables 24 and 25 in Appendix B. Specific listed content areas where different from those detailed in the State Manual are shown separately.) From these tallies a ranking of most emphasized goals and objectives for West Virginia schools was developed. These content areas considered "most preferred" by these rankings are economics, geography, and law-related education for Kindergarten through Grade 3, Grade 4 through Grade 6, and Grades 7 and 8.

Other "highly ranked" content areas in the West Virginia Social Studies Goals and Objectives include energy and multicultural education for Kindergarten through Grade 3 and global education and U. S. history for Grades 4 through Grade 6. World history was listed as a preference for Grades 7 and 8 as was state history studies, which was also a high priority for Grades 4 through Grade 6. A comparison of the respondent rankings of social studies instructional content areas with those published by the West Virginia Department of Education shows little congruence. The only areas of highly ranked preference are for multicultural education in Kindergarten through Grade 3 and for U. S. history and state history (studies) in Grades 4 though Grade 6.

\section{$\underline{\text { Conclusions and Implications }}$}

This study of how pre-service social studies teachers rank social studies instructional activities and social studies content areas does have some 
implications for further educational research and teacher education practices. These would seem to fall into two areas: (1) teacher education, and (2) preconceptions and background of students.

\section{Teacher Education}

The results of this research should be of interest to those educating the educators. State mandated goals and objectives, while in agreement with these ranked by respondents, do not show up heavily in this study. This researcher does not find this cause for alarm. It seems likely that short-term pragmatic content, such as drug education, simply caused a less preferred ranking to appear for more traditional content. Further, without additional definition of some of the content areas, i.e., political science, it seems probable that many respondents simply interpreted the terms as to their college course content and dismissed the term as not relevant to elementary education. Still, for those responsible for promulgating the various voluntary standards, these conclusions might give cause for going back to study exactly why these various content areas were not specifically ranked highly. In terms of educational activities, Goodman and Adler (1985, p. 17) have said that their work:

"suggest the preparation courses should focus on the skills of curriculum development and implementation."

Students need to learn how to develop curriculum based on their own and their pupils' intellectual interests. Preparation courses should teach students 
to choose worthwhile topics of study; develop the themes, concepts, or areas of content that make up this topic; research those themes to increase their own level of knowledge on this topic; discover resources that children can use to explore these themes; develop activities that illuminate the themes of this topic and promote creativity and thoughtfulness among pupils.

The emphasis in the above quote is by this author to whom it would appear that the teacher education program(s), at least at West Virginia University, to the extent that this research studied them are giving the teachers for the next millennium appropriate preparation.

Respondents preferred instructional activities for classroom use for their educational value, not those which might be more popular with students. They appeared to make their choices not on the bases of activities which were easier to grade or which might facilitate classroom control but on the basis of age/grade/cognitive ability of the student.

Additionally, their choices, highly ranked or low, were not limited to a few activities. It would appear that these future teachers made some sophisticated discernment. For example, for each of the first three research questions, all 14 educational activities were ranked in some way across the grade clusters (except for rankings for perceived student enjoyment where 
writing activities made neither a positive nor negative appearance at any grade level).

Finally, in terms of content areas ranked, respondents' rankings were not really congruent with those endorsed by the State of West Virginia. However, those content areas which respondents listed with high rankings are currently seen as important for study in our society at this time. They further are typically short-term units. This author feels positive more traditional goals will be met: they are lower ranked but will be attended to as soon as immediate content needs (e.g., drug education) are addressed.

\section{Preconceptions and Background}

Authors (Sunal and Haas, 1993, Thornton, 1991) have been concerned with the background, experiences, and preconceptions that educators bring with them to their profession. While such preconceptions are beyond the scope of this paper, such preconceptions or respondent background might possibly explain the disparity between the different research efforts presented here. This seems especially useful for those whose objective is influencing educators' choices in their classroom.

The present study replicated the knowledge of what pre-service elementary teachers judge to be important in their repertoire of instructional activities and judge to be of importance in the various social studies content areas for students in social studies classes. Pre-service elementary teachers have shown that they prefer instructional activities which facilitate learning 
and that above the primary grades they pay less attention to what they believe students would most enjoy. They have shown an ability to discern the usefulness of different instructional activities for their students at different grade levels. While they do not list official content areas they do list useful immediately pragmatic content which will undoubtedly be more short-term study, leaving time ultimately for the more traditional defined content.

Ultimately, this author found the data to show the respondents as having a discerning and sophisticated knowledge to deal with their future responsibilities: a very positive message about social studies in the new millennium.

\section{Further Research}

It would seem appropriate to attempt a better explanation of the research in this area. For example, it would be useful to discern why content areas emphasized by various standards, such as those of the State of West Virginia, were not highly ranked. Further, it seems from this research, that respondents did not define traditional social science subject matter (e.g., Political Science) as part of the curriculum for elementary social studies. It would seem appropriate to find to what extent pre-service and in-service teachers believe the traditional social sciences to be a part of the social studies; to what extent they believe the traditional social sciences to be a part of the newer multidisciplinary studies such as Multicultural Education; and to what extent they believe the traditional social sciences to be a part of traditional 
social studies content areas such as Civics. The explanation of respondents' answers might be found by simply asking them on the questionnaire to explain their rankings. Perhaps, a researcher could ask respondents to think aloud as they completed the research instrument and thus take note of their acknowledged reasoning. A possibly more useful but certainly more time consuming technique for checking respondent rationale would be to evaluate the rankings first and then go back to interview individuals regarding their answers.

Additional research into instructional activities might also look at the underlying reasons for the rankings which respondents made. Personal preference rankings are apparently based on educational value rankings for these respondents. Educational value rankings have been shown to have a reality base. See Figure 6. This research should be replicated and could be extended to look for other explanations. Perceived student enjoyment, for example, may well be based on respondent intuition, but it would be interesting to see if choices were based on prior experiences of respondents as students. Indeed, the entire field of preconceptions and the nature of how preconceptions that students bring to their college experiences affect those experiences and consequent outcomes and choices in their own classrooms could be of value to education professors. 


\section{$\underline{\text { References }}$}

Adler, Susan. (1994). Standards in Social Studies and the Young Learner, 6 , (3). 17-19, 22.

Alleman, J. \& Brophy, J. (1995). Instructional activities: Preference, enjoyment, and educational value. Paper presented at American Educational Research Association. San Francisco, CA.

Alleman, J. \& Brophy. J. (1994). Teaching that lasts: College students' reports of learning activities experienced in the elementary school social studies. Paper presented at the American Educational Research Association, New Orleans.

Alleman, J. \& Brophy, J. (1994). Trade-offs embedded in the literary approach to early elementary social studies. Social Studies and the Young Learner, 6 (3). 6-8.

America 2000 (1991). U. S. Department of Education: Washington, DC.

Barr, R. D., Barth, J. L., \& Shermis, S. S. (1977). Defining the social studies. National Council for the Social Studies: Arlington, VA.

The Benedum project: A new vision for teacher education at West Virginia

University. Second Revision. Morgantown, WV: West Virginia University. (1994). p. 6.

Bloch, Marianne N. (1986). Social education for young children. An Invitation to Young Children. Editor: Catherine Cornbleth. NCSS Bulletin, No. 77, pp. 91-108. 
Brophy, Jere \& Alleman, J. (1991). Activities as instructional tools: A framework for analysis and evaluation. Educational Researcher, 20. (4), 9-23.

Cardis, R. J. \& Risinger, C. F. (1994). Contemporary trends in social studies. Social Studies and the Young Learner, 57. (2), 4-22.

Carter, D. S. G. \& Hacker, R. G. (Winter, 1998). A typology of social studies teaching process. Theory and Research in Social Education, XVI. (1), $51-67$

Dance, Charles. (1996). An annotated bibliography regarding the correlates of students' negative attitudes towards the subject of social studies in the elementary school curriculum. (ERIC No. ED280771).

Davis, O. L., Jr., ed. (1996). NCSS in Retrospect. National Council for the Social Studies: Arlington, VA.

Diem, Richard A. (1997). Information Technology and Civic Education, Interactive Technologies and the Social Studies, (Chapter 5). Peter H. Martorella, ed. Albany, NY: State University of New York Press.

Elementary social studies: Research as a guide to practice. (1986). National Council for the Social Studies: Washington DC, Bulletin No. 79.

Eric Clearinghouse for Social Studies, ERIC/chESS Digests. (1999). Indiana University [On-line]. Available: http://www.indiana.edu/ sssdc/digest.html. 
The Essentials Statement. (1980). National Council for the Social Studies: Washington, DC.

Expectations of excellence: National standards for social studies. (1994). National Council for the Social Studies: Arlington, VA.

Finkelstein, Judith M. (February, 1993). Primary elementary school studies education: A status report. Social Education, 57. (2), 64-69.

Freese, J. R. (1997). Using the National Geography Standards to Integrate Children's Social Studies and the Young Learner, 10. (2), 22-24.

Goodman, Jesse \& Adler, Susan. (1985). Becoming an elementary social studies teacher: A study of perspectives. Theory and Research in Social Education, XIII. (2), 1-20.

Grady, Emily. The portfolio approach to assessment fastback 341. Bloomington, Indiana: Phi Delta Kappa Educational Foundation.

Grant, S. G. (Summer, 1969). Locating authority over content and pedagogy: Cross-current influences on teachers thinking and practice. Theory and Research in Social Education, 24. (3), 237-272.

Handley, L. M. \& Adler, Susan. (1994). Standards in social studies: Curriculum concerns. Social Studies and the Young Learner, 6. (3), 1722.

Haas, Mary E. \& Laughlin, Margaret A. (Eds.). (1997). Meeting the standards: Social studies for K-6 educators. National Council for the Social Studies: Washington, DC. 
Hoge, John D. (1996). Effective elementary social studies. Belmont, California: Wadsworth Publishing Company.

Jarolimek, John \& Parker, Walter C. (1990). Social studies in elementary education. (Ninth edition). New York: MacMillan Publishing Company. Jenness, David. (No date). Making sense of social studies. New York: MacMillan Publishing Company.

Kaltsounis, Theodore. (1987). Teaching social studies in the elementary school: The basics for citizenship. Englewood Cliffs, New Jersey: Prentice Hall, Inc.

Mahood, W., Bremer, L. \& Lowe, W. T. (1991). Teaching social studies in middle and senior high school. Merril Publishing.

Marockie, Henry R. Instructional goals and objectives for West Virginia schools. Charleston, WV: West Virginia Department of Education, 1995. Martorella, Peter H. (1994). Social studies for elementary school children: Developing young citizens. New York: MacMillan Publishing Company. Maryland School Performance Program: Grades K-8 Social Studies Rationale. (1999). Montgomery County Public School. Available: http://www.mcps.k12.md.us/curriculum/socialstd/mspaprationale.htm 1.

McKinney-Browning, M. C. (1994). What's ahead for social studies? Social Studies and the Young Learner, 6. (3), 29-32.

Murray, C. Kenneth. (1997). Preconceptions held by preservice secondary

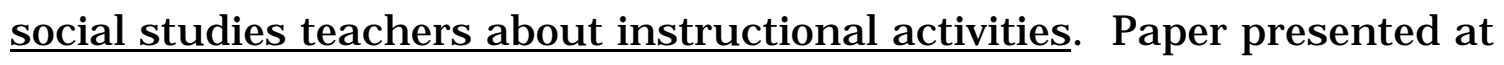


the Eastern Education Research Association Annual Meeting, Hilton Head, SC.

Murray, C. Kenneth. (1998). Preference rankings of primary social studies content areas by social studies education majors. Paper in preparation. West Virginia University, Morgantown, WV.

Murray, C. Kenneth. (1999). Interview. West Virginia University, Morgantown, WV.

NCSS Task Force, Social studies for early childhood and elementary school children preparing for the $21^{\text {st }}$ century. (June, 1998). National Council for the Social Studies. Available: http://www.ncss.org/standards/positions/elementary.html.

Nelson, Lynn R. (1991). Making sense of social studies: Maginot line for the field. Theory and Research in Social Studies Education, XIX, (3). 311316.

Parker, W. C. \& Jarolimek, J. (1997). Social Studies in Elementary Education. (Tenth Edition). Upper Saddle River, NJ: Prentice-Hall, Inc.

Ryan, Frank L. (1980). The social studies sourcebook: Ideas for teaching in the elementary and middle school. Boston, MA: Allyn and Bacon, Inc.

Schug, M., Todd, R. \& Beery, R. (1984). Why kids don’t like social studies. Social Education, 48. pp. 382-387.

Shaver, J. P., Davis, O. L. \& Helbern, S. W. (1980). What are the needs in precollege science, mathematics, and social studies education? Views from the field. Washington, DC: National Science Foundation. 
Siler, Carl R. (1998). Spatial dynamics: An alternative teaching tool in the social studies. Available:

http://www.indiana.edu/ncssdc/spatdig.html.

Social Sciences Reference Committee. (1999). Social studies: A curriculum guide for the elementary level. Regina, Saskatchewan. Available: http://www.sasked.gov.sk.ca/docs/elemsoc/adminbul/pur.html.

Stuckey, E. K. (1990). Putting social studies back into early primary classrooms. Social Studies and the Young Learner, 4. (2), 13-15.

Sunal, C. S. \& Haas, M. E. (Eds.) (1993). Social studies and the elementary/middle school student. Fort Worth, TX: Harcourt Brace Javonovich College Publishers.

Sunal, Cynthia Szmanski, Smith, Coralee, Sunal, Dennis, Britt, Judy. (1998). Using the internet to create meaningful instruction. Social Studies, 89. (1), 13-17.

Thornton, Stephen J. (1991). Teacher as curricular-instructional gatekeeper in social studies. (Chapter 19, pp. 237-248) in Handbook of Research in Social Studies Teaching and Learning. James B. Shaver (Ed.). New York, NY: MacMillan and Co.

Walsh, Huber. (1980). Introducing the young child to the social world. New York: MacMillan Publishing Co.

Wilen, William W. (1988). Review of pedagogical perspectives. (Chapter 15) in Questioning and Discussion: A Multidisciplinary Study. J. T. Dillon, Ed. Norwood, NJ: Ablex Publishing Company. 
Woolever, Roberta \& Scott, Kathryn P. (1988). Active learning in social studies: Promoting cognitive and social growth. Glenview, IL: Scott, Foresman and Company. 


\section{APPENDIX A}

Please evaluate the following educational activities as if you were already an elementary social studies teacher. Please rank from most educational value (14) to least educational value (1) for each of the following instructional activities. In Column I, rank order the activities for students in grades K-3. In Column II, rank for grades 4-6. In Column III, rank for grades 7-8.

\begin{tabular}{|c|c|c|c|}
\hline & Grades K-3 & Grades 5-6 & Grades 7-8 \\
\hline Activities & $\begin{array}{l}\text { Educational } \\
\text { Value }\end{array}$ & $\begin{array}{l}\text { Educational } \\
\text { Value }\end{array}$ & $\begin{array}{l}\text { Educational } \\
\text { Value }\end{array}$ \\
\hline 1. Reading and discussing text. & & & \\
\hline $\begin{array}{l}\text { 2. Reinforcing activities: seatwork (crossword } \\
\text { puzzles, fill-in-the-blank, matching, locating and } \\
\text { coloring correct answers, vocabulary and skill } \\
\text { reinforcement). }\end{array}$ & & & \\
\hline $\begin{array}{l}\text { 3. Reinforcing activities: class discussion (open- } \\
\text { ended questions, reading and interpreting a map, } \\
\text { graph, cartoon, or paragraph). }\end{array}$ & & & \\
\hline 4. Using games, simulations or computer games. & & & \\
\hline 5. Viewing slides, filmstrips, movies, or videos. & & & \\
\hline $\begin{array}{l}\text { 6. Listening to tapes, lectures, or dramatic } \\
\text { readings by the teacher or resource person. }\end{array}$ & & & \\
\hline 7. Field trips. & & & \\
\hline 8. Research project. & & & \\
\hline $\begin{array}{l}\text { 9. Issue focused interaction (debate, mock trial, } \\
\text { panel discussions). }\end{array}$ & & & \\
\hline $\begin{array}{l}\text { 10. Oral language experience (story-telling with } \\
\text { pictures or puppets, writing/singing songs, or } \\
\text { conducting structured interviews). }\end{array}$ & & & \\
\hline $\begin{array}{l}\text { 11. Performing from scripts (plays, puppet } \\
\text { shows, pageants). }\end{array}$ & & & \\
\hline $\begin{array}{l}\text { 12. Constructing/making (dioramas, panoramas, } \\
\text { shadow boxes, displays, salt/flour maps, artifacts, } \\
\text { weaving, drying fruit, and making soup). }\end{array}$ & & & \\
\hline 13. Art-related activities (painting, drawing). & & & \\
\hline $\begin{array}{l}\text { 14. Writing activities (journals, logs, letters to pen } \\
\text { pals, letters requesting information, writing plays } \\
\text { or dialogue). }\end{array}$ & & & \\
\hline
\end{tabular}


Please evaluate the following educational activities as if you were already an elementary social studies teacher. Please rank from most enjoyable value (14) to least enjoyable value (1) for each of the following instructional activities. In Column I, rank order the activities for students in grades K-3. In Column II, rank for grades 4-6. In Column III, rank for grades 7-8.

\begin{tabular}{|l|c|c|c|}
\cline { 2 - 4 } \multicolumn{1}{c|}{} & Grades K-3 & Grades 5-6 & Grades 7-8 \\
\hline Activities & $\begin{array}{c}\text { Enjoyable } \\
\text { Activity }\end{array}$ & $\begin{array}{c}\text { Enjoyable } \\
\text { Activity }\end{array}$ & $\begin{array}{c}\text { Enjoyable } \\
\text { Activity }\end{array}$ \\
\hline 1. Reading and discussing text. & & \\
\hline $\begin{array}{l}\text { 2. Reinforcing activities: seatwork (crossword } \\
\text { puzzles, fill-in-the-blank, matching, locating and } \\
\text { coloring correct answers, vocabulary and skill } \\
\text { reinforcement). }\end{array}$ & & \\
\hline $\begin{array}{l}\text { 3. Reinforcing activities: class discussion (open- } \\
\text { ended questions, reading and interpreting a map, } \\
\text { graph, cartoon, or paragraph). }\end{array}$ & & \\
\hline $\begin{array}{l}\text { 4. Using games, simulations or computer games. } \\
\text { 5. Viewing slides, filmstrips, movies, or videos. }\end{array}$ & & \\
\hline $\begin{array}{l}\text { 6. Listening to tapes, lectures, or dramatic } \\
\text { readings by the teacher or resource person. }\end{array}$ & & \\
\hline 7. Field trips. & & & \\
\hline 8. Research project. & & \\
\hline $\begin{array}{l}\text { 9. Issue focused interaction (debate, mock trial, } \\
\text { panel discussions). }\end{array}$ & & & \\
\hline $\begin{array}{l}\text { 10. Oral language experience (story-telling with } \\
\text { pictures or puppets, writing/singing songs, or } \\
\text { conducting structured interviews). }\end{array}$ & & & \\
\hline $\begin{array}{l}\text { 11. Performing from scripts (plays, puppet } \\
\text { shows, pageants). }\end{array}$ & & & \\
\hline $\begin{array}{l}\text { 12. Constructing/making (dioramas, panoramas, } \\
\text { shadow boxes, displays, salt/flour maps, artifacts, } \\
\text { weaving, drying fruit, and making soup). }\end{array}$ & & & \\
\hline 13. Art-related activities (painting, drawing). & & \\
\hline $\begin{array}{l}\text { 14. Writing activities (journals, logs, letters to pen } \\
\text { pals, letters requesting information, writing plays } \\
\text { or dialogue). }\end{array}$ & & & \\
\hline
\end{tabular}


Please evaluate the following educational activities as if you were already an elementary social studies teacher. Please rank from most preferred activities (14) to least preferred activity (1) for each of the following instructional activities. In Column I, rank order the activities for students in grades K-3. In Column II, rank for grades 4-6. In Column III, rank for grades 7-8.

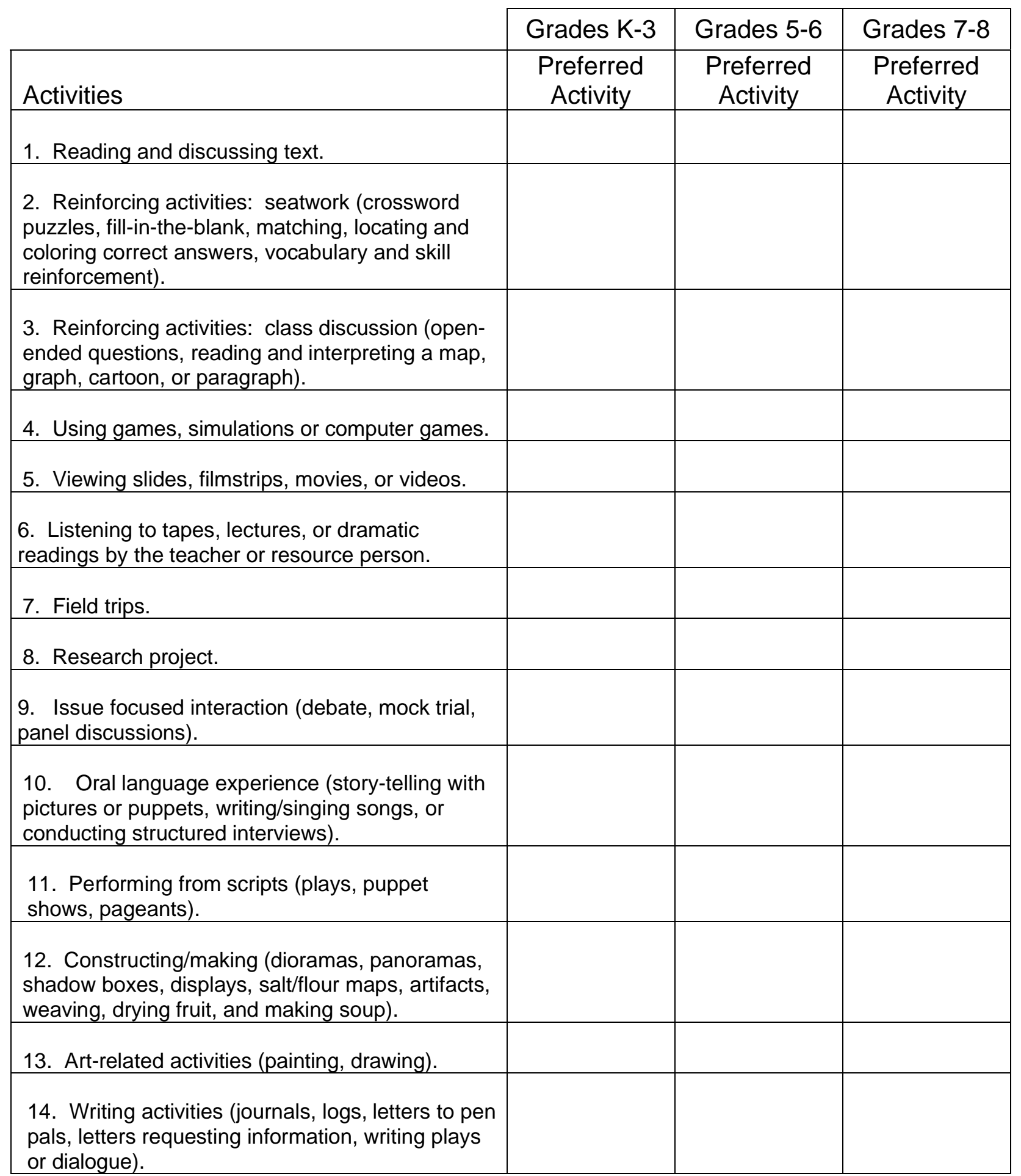


Please evaluate the following social studies areas as if you were already an elementary social studies teacher. In Column I, we are interested in the five content areas which you would most prefer to teach (rank from 1 through 5) and those content areas which you would least prefer to teach (rank from 21 through 25) in grades K-3. In Column II, respond for grades 4-6, and in Column III, respond for grades 7-8.

Number 1-5=Most Preferred Content

Number 21-25=Least Preferred Content

\begin{tabular}{|c|c|c|c|}
\hline Content Areas & Grades K-3 & Grades 4-5 & Grades 7-8 \\
\hline \multicolumn{4}{|l|}{ Anthropology } \\
\hline \multicolumn{4}{|l|}{ Archeology } \\
\hline \multicolumn{4}{|l|}{ Career Education } \\
\hline \multicolumn{4}{|l|}{ Conflict Resolution } \\
\hline \multicolumn{4}{|l|}{ Current Events } \\
\hline \multicolumn{4}{|l|}{ Drug Education } \\
\hline \multicolumn{4}{|l|}{ Economics } \\
\hline \multicolumn{4}{|l|}{ Energy \& Environmental Education } \\
\hline \multicolumn{4}{|l|}{ Future Studies } \\
\hline \multicolumn{4}{|l|}{ Gender Issues } \\
\hline \multicolumn{4}{|l|}{ Geography } \\
\hline \multicolumn{4}{|l|}{ Global Education } \\
\hline \multicolumn{4}{|l|}{ Humanities } \\
\hline \multicolumn{4}{|l|}{ Law-related Education } \\
\hline \multicolumn{4}{|l|}{ Multicultural Education } \\
\hline \multicolumn{4}{|l|}{ Philosophy } \\
\hline \multicolumn{4}{|l|}{ Political Science } \\
\hline \multicolumn{4}{|l|}{ Psychology } \\
\hline \multicolumn{4}{|l|}{ Religion } \\
\hline \multicolumn{4}{|l|}{ Sociology } \\
\hline \multicolumn{4}{|l|}{ State History } \\
\hline \multicolumn{4}{|l|}{ U. S. History } \\
\hline \multicolumn{4}{|l|}{ Values Education } \\
\hline Volunteer/required Social Serv. $\mathrm{Pr}$ & & & \\
\hline World History & & & \\
\hline
\end{tabular}


Responses to this survey are anonymous, but we would like to know something about those who are responding. Please check the correct box for each of the following.

1. Age

$\square$ 18-22

ए 23-27

$\square \quad 28-32$

प 32 and above
2. Sex

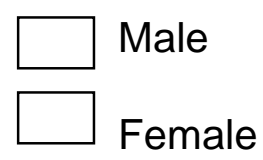

Female
3. Grade Point Average

$\square$ below 2.0
$\square$ 2.0-2.49
$\square$ 2.5-2.99
$\square$ 3.0-3.49
$\square .5-4.0$

4. Classification
$\square$ Freshman
Sophomore
$\square$ Junior
Senior
Fifth Year 


\section{APPENDIX B}

Table 1

Summary of Responses to Question 1

Weighted Responses and Rankings of Educational Value for Grades K-3

\begin{tabular}{|c|c|c|}
\hline \multirow[b]{2}{*}{ Activities } & \multicolumn{2}{|c|}{ Grades K-3 } \\
\hline & $\begin{array}{l}\text { Weighted } \\
\text { Responses }\end{array}$ & Rankings \\
\hline 1. Reading and discussing text. & 433 & 1 \\
\hline $\begin{array}{l}\text { 2. Reinforcing activities: seatwork (crossword puzzles, fill-in-the- } \\
\text { blank, matching, locating and coloring correct answers, vocabulary } \\
\text { and skill reinforcement). }\end{array}$ & 435 & 2 \\
\hline $\begin{array}{l}\text { 3. Reinforcing activities: class discussion (open-ended questions, } \\
\text { reading and interpreting a map, graph, cartoon, or paragraph). }\end{array}$ & 592 & 8 \\
\hline 4. Using games, simulations or computer games. & 667 & 11 \\
\hline 5. Viewing slides, filmstrips, movies, or videos. & 538 & 6 \\
\hline $\begin{array}{l}\text { 6. Listening to tapes, lectures, or dramatic readings by the teacher or } \\
\text { resource person. }\end{array}$ & 513 & 5 \\
\hline 7. Field trips. & 792 & 13 \\
\hline 8. Research project. & 439 & 3 \\
\hline 9. Issue focused interaction (debate, mock trial, panel discussions). & 482 & 4 \\
\hline $\begin{array}{l}\text { 10. Oral language experience (story-telling with pictures or puppets, } \\
\text { writing/singing songs, or conducting structured interviews). }\end{array}$ & 841 & 14 \\
\hline 11. Performing from scripts (plays, puppet shows, pageants). & 681 & 12 \\
\hline $\begin{array}{l}\text { 12. Constructing/making (dioramas, panoramas, shadow boxes, } \\
\text { displays, salt/flour maps, artifacts, weaving, drying fruit, and making } \\
\text { soup). }\end{array}$ & 660 & 10 \\
\hline 13. Art-related activities (painting, drawing). & 611 & 9 \\
\hline $\begin{array}{l}\text { 14. Writing activities (journals, logs, letters to pen pals, letters } \\
\text { requesting information, writing plays or dialogue). }\end{array}$ & 576 & 7 \\
\hline
\end{tabular}


Table 2

Summary of Responses to Question 1

Weighted Responses and Rankings of Educational Value for Grades 4-6

\begin{tabular}{|c|c|c|}
\hline \multirow[b]{2}{*}{ Activities } & \multicolumn{2}{|c|}{ Grades 4-6 } \\
\hline & $\begin{array}{c}\text { Weighted } \\
\text { Responses }\end{array}$ & Rankings \\
\hline 1. Reading and discussing text. & 582 & 4 \\
\hline $\begin{array}{l}\text { 2. Reinforcing activities: seatwork (crossword puzzles, fill-in-the- } \\
\text { blank, matching, locating and coloring correct answers, vocabulary } \\
\text { and skill reinforcement). }\end{array}$ & 456 & 1 \\
\hline $\begin{array}{l}\text { 3. Reinforcing activities: class discussion (open-ended questions, } \\
\text { reading and interpreting a map, graph, cartoon, or paragraph). }\end{array}$ & 767 & 13 \\
\hline 4. Using games, simulations or computer games. & 661 & 7 \\
\hline 5. Viewing slides, filmstrips, movies, or videos. & 629 & 5 \\
\hline $\begin{array}{l}\text { 6. Listening to tapes, lectures, or dramatic readings by the teacher or } \\
\text { resource person. }\end{array}$ & 553 & 3 \\
\hline 7. Field trips. & 825 & 14 \\
\hline 8. Research project. & 683 & 9 \\
\hline 9. Issue focused interaction (debate, mock trial, panel discussions). & 689 & 10 \\
\hline $\begin{array}{l}\text { 10. Oral language experience (story-telling with pictures or puppets, } \\
\text { writing/singing songs, or conducting structured interviews). }\end{array}$ & 724 & 12 \\
\hline 11. Performing from scripts (plays, puppet shows, pageants). & 640 & 6 \\
\hline $\begin{array}{l}\text { 12. Constructing/making (dioramas, panoramas, shadow boxes, } \\
\text { displays, salt/flour maps, artifacts, weaving, drying fruit, and making } \\
\text { soup). }\end{array}$ & 667 & 8 \\
\hline 13. Art-related activities (painting, drawing). & 521 & 2 \\
\hline $\begin{array}{l}\text { 14. Writing activities (journals, logs, letters to pen pals, letters } \\
\text { requesting information, writing plays or dialogue). }\end{array}$ & 698 & 11 \\
\hline
\end{tabular}


Table 3

Summary of Responses to Question 1

Weighted Responses and Rankings of Educational Value for Grades 7-8

\begin{tabular}{|c|c|c|}
\hline \multirow[b]{2}{*}{ Activities } & \multicolumn{2}{|c|}{ Grades 7-8 } \\
\hline & $\begin{array}{l}\text { Weighted } \\
\text { Responses }\end{array}$ & Rankings \\
\hline 1. Reading and discussing text. & 610 & 7 \\
\hline $\begin{array}{l}\text { 2. Reinforcing activities: seatwork (crossword puzzles, fill-in-the- } \\
\text { blank, matching, locating and coloring correct answers, vocabulary } \\
\text { and skill reinforcement). }\end{array}$ & 412 & 1 \\
\hline $\begin{array}{l}\text { 3. Reinforcing activities: class discussion (open-ended questions, } \\
\text { reading and interpreting a map, graph, cartoon, or paragraph). }\end{array}$ & 763 & 13 \\
\hline 4. Using games, simulations or computer games. & 600 & 6 \\
\hline 5. Viewing slides, filmstrips, movies, or videos. & 511 & 3 \\
\hline $\begin{array}{l}\text { 6. Listening to tapes, lectures, or dramatic readings by the teacher or } \\
\text { resource person. }\end{array}$ & 527 & 4 \\
\hline 7. Field trips. & 775 & 14 \\
\hline 8. Research project. & 732 & 12 \\
\hline 9. Issue focused interaction (debate, mock trial, panel discussions). & 715 & 11 \\
\hline $\begin{array}{l}\text { 10. Oral language experience (story-telling with pictures or puppets, } \\
\text { writing/singing songs, or conducting structured interviews). }\end{array}$ & 685 & 9 \\
\hline 11. Performing from scripts (plays, puppet shows, pageants). & 549 & 5 \\
\hline $\begin{array}{l}\text { 12. Constructing/making (dioramas, panoramas, shadow boxes, } \\
\text { displays, salt/flour maps, artifacts, weaving, drying fruit, and making } \\
\text { soup). }\end{array}$ & 618 & 8 \\
\hline 13. Art-related activities (painting, drawing). & 473 & 2 \\
\hline $\begin{array}{l}\text { 14. Writing activities (journals, logs, letters to pen pals, letters } \\
\text { requesting information, writing plays or dialogue). }\end{array}$ & 690 & 10 \\
\hline
\end{tabular}




\section{Table 4 \\ Summary of Responses to Question 1 \\ Comparison of Grade Level Rankings of Educational Value}

\begin{tabular}{|c|c|c|c|}
\hline \multirow[b]{2}{*}{ Activities } & \multicolumn{3}{|c|}{ Rankings } \\
\hline & Grades K-3 & Grades 4-6 & Grades 7-8 \\
\hline 1. Reading and discussing text. & 1 & 4 & 7 \\
\hline $\begin{array}{l}\text { 2. Reinforcing activities: seatwork (crossword } \\
\text { puzzles, fill-in-the-blank, matching, locating and } \\
\text { coloring correct answers, vocabulary and skill } \\
\text { reinforcement). }\end{array}$ & 2 & 1 & 1 \\
\hline $\begin{array}{l}\text { 3. Reinforcing activities: class discussion (open- } \\
\text { ended questions, reading and interpreting a map, } \\
\text { graph, cartoon, or paragraph). }\end{array}$ & 8 & 13 & 13 \\
\hline 4. Using games, simulations or computer games. & 11 & 7 & 6 \\
\hline 5. Viewing slides, filmstrips, movies, or videos. & 6 & 5 & 3 \\
\hline $\begin{array}{l}\text { 6. Listening to tapes, lectures, or dramatic } \\
\text { readings by the teacher or resource person. }\end{array}$ & 5 & 3 & 4 \\
\hline 7. Field trips. & 13 & 14 & 14 \\
\hline 8. Research project. & 3 & 9 & 12 \\
\hline $\begin{array}{l}\text { 9. Issue focused interaction (debate, mock trial, } \\
\text { panel discussions). }\end{array}$ & 4 & 10 & 11 \\
\hline $\begin{array}{l}\text { 10. Oral language experience (story-telling with } \\
\text { pictures or puppets, writing/singing songs, or } \\
\text { conducting structured interviews). }\end{array}$ & 14 & 12 & 9 \\
\hline $\begin{array}{l}\text { 11. Performing from scripts (plays, puppet } \\
\text { shows, pageants). }\end{array}$ & 12 & 6 & 5 \\
\hline $\begin{array}{l}\text { 12. Constructing/making (dioramas, panoramas, } \\
\text { shadow boxes, displays, salt/flour maps, artifacts, } \\
\text { weaving, drying fruit, and making soup). }\end{array}$ & 10 & 8 & 8 \\
\hline 13. Art-related activities (painting, drawing). & 9 & 2 & 2 \\
\hline $\begin{array}{l}\text { 14. Writing activities (journals, logs, letters to pen } \\
\text { pals, letters requesting information, writing plays } \\
\text { or dialogue). }\end{array}$ & 7 & 11 & 10 \\
\hline
\end{tabular}




\section{Table 5}

Summary of Responses to Question 2

Weighted Responses and Rankings of Enjoyable Activities for Grades K-3

\begin{tabular}{|c|c|c|}
\hline \multirow[b]{2}{*}{ Activities } & \multicolumn{2}{|c|}{ Grades K-3 } \\
\hline & $\begin{array}{c}\text { Weighted } \\
\text { Responses }\end{array}$ & Rankings \\
\hline 1. Reading and discussing text. & 320 & 1 \\
\hline $\begin{array}{l}\text { 2. Reinforcing activities: seatwork (crossword puzzles, fill-in-the- } \\
\text { blank, matching, locating and coloring correct answers, vocabulary } \\
\text { and skill reinforcement). }\end{array}$ & 412 & 3 \\
\hline $\begin{array}{l}\text { 3. Reinforcing activities: class discussion (open-ended questions, } \\
\text { reading and interpreting a map, graph, cartoon, or paragraph). }\end{array}$ & 454 & 4 \\
\hline 4. Using games, simulations or computer games. & 679 & 9 \\
\hline 5. Viewing slides, filmstrips, movies, or videos. & 630 & 8 \\
\hline $\begin{array}{l}\text { 6. Listening to tapes, lectures, or dramatic readings by the teacher or } \\
\text { resource person. }\end{array}$ & 501 & 6 \\
\hline 7. Field trips. & 856 & 14 \\
\hline 8. Research project. & 367 & 2 \\
\hline 9. Issue focused interaction (debate, mock trial, panel discussions). & 500 & 5 \\
\hline $\begin{array}{l}\text { 10. Oral language experience (story-telling with pictures or puppets, } \\
\text { writing/singing songs, or conducting structured interviews). }\end{array}$ & 801 & 12 \\
\hline 11. Performing from scripts (plays, puppet shows, pageants). & 731 & 10 \\
\hline $\begin{array}{l}\text { 12. Constructing/making (dioramas, panoramas, shadow boxes, } \\
\text { displays, salt/flour maps, artifacts, weaving, drying fruit, and making } \\
\text { soup). }\end{array}$ & 766 & 11 \\
\hline 13. Art-related activities (painting, drawing). & 842 & 13 \\
\hline $\begin{array}{l}\text { 14. Writing activities (journals, logs, letters to pen pals, letters } \\
\text { requesting information, writing plays or dialogue). }\end{array}$ & 571 & 7 \\
\hline
\end{tabular}


Table 6

Summary of Responses to Question 2

Weighted Responses and Rankings of Enjoyable Activities for Grades 4-6

\begin{tabular}{|c|c|c|}
\hline \multirow[b]{2}{*}{ Activities } & \multicolumn{2}{|c|}{ Grades 4-6 } \\
\hline & $\begin{array}{l}\text { Weighted } \\
\text { Responses }\end{array}$ & Rankings \\
\hline 1. Reading and discussing text. & 311 & 1 \\
\hline $\begin{array}{l}\text { 2. Reinforcing activities: seatwork (crossword puzzles, fill-in-the- } \\
\text { blank, matching, locating and coloring correct answers, vocabulary } \\
\text { and skill reinforcement). }\end{array}$ & 402 & 3 \\
\hline $\begin{array}{l}\text { 3. Reinforcing activities: class discussion (open-ended questions, } \\
\text { reading and interpreting a map, graph, cartoon, or paragraph). }\end{array}$ & 515 & 5 \\
\hline 4. Using games, simulations or computer games. & 763 & 11 \\
\hline 5. Viewing slides, filmstrips, movies, or videos. & 681 & 9 \\
\hline $\begin{array}{l}\text { 6. Listening to tapes, lectures, or dramatic readings by the teacher or } \\
\text { resource person. }\end{array}$ & 504 & 4 \\
\hline 7. Field trips. & 883 & 14 \\
\hline 8. Research project. & 387 & 2 \\
\hline 9. Issue focused interaction (debate, mock trial, panel discussions). & 630 & 6 \\
\hline $\begin{array}{l}\text { 10. Oral language experience (story-telling with pictures or puppets, } \\
\text { writing/singing songs, or conducting structured interviews). }\end{array}$ & 660 & 8 \\
\hline 11. Performing from scripts (plays, puppet shows, pageants). & 706 & 10 \\
\hline $\begin{array}{l}\text { 12. Constructing/making (dioramas, panoramas, shadow boxes, } \\
\text { displays, salt/flour maps, artifacts, weaving, drying fruit, and making } \\
\text { soup). }\end{array}$ & 780 & 12 \\
\hline 13. Art-related activities (painting, drawing). & 802 & 13 \\
\hline $\begin{array}{l}\text { 14. Writing activities (journals, logs, letters to pen pals, letters } \\
\text { requesting information, writing plays or dialogue). }\end{array}$ & 642 & 7 \\
\hline
\end{tabular}


Table 7

Summary of Responses to Question 2

Weighted Responses and Rankings of Enjoyable Activities for Grades 7-8

\begin{tabular}{|c|c|c|}
\hline \multirow[b]{2}{*}{ Activities } & \multicolumn{2}{|c|}{ Grades 7-8 } \\
\hline & $\begin{array}{l}\text { Weighted } \\
\text { Responses }\end{array}$ & Rankings \\
\hline 1. Reading and discussing text. & 344 & 1 \\
\hline $\begin{array}{l}\text { 2. Reinforcing activities: seatwork (crossword puzzles, fill-in-the- } \\
\text { blank, matching, locating and coloring correct answers, vocabulary } \\
\text { and skill reinforcement). }\end{array}$ & 413 & 2 \\
\hline $\begin{array}{l}\text { 3. Reinforcing activities: class discussion (open-ended questions, } \\
\text { reading and interpreting a map, graph, cartoon, or paragraph). }\end{array}$ & 554 & 5 \\
\hline 4. Using games, simulations or computer games. & 800 & 13 \\
\hline 5. Viewing slides, filmstrips, movies, or videos. & 658 & 10 \\
\hline $\begin{array}{l}\text { 6. Listening to tapes, lectures, or dramatic readings by the teacher or } \\
\text { resource person. }\end{array}$ & 506 & 4 \\
\hline 7. Field trips. & 923 & 14 \\
\hline 8. Research project. & 433 & 3 \\
\hline 9. Issue focused interaction (debate, mock trial, panel discussions). & 747 & 11 \\
\hline $\begin{array}{l}\text { 10. Oral language experience (story-telling with pictures or puppets, } \\
\text { writing/singing songs, or conducting structured interviews). }\end{array}$ & 565 & 6 \\
\hline 11. Performing from scripts (plays, puppet shows, pageants). & 612 & 7 \\
\hline $\begin{array}{l}\text { 12. Constructing/making (dioramas, panoramas, shadow boxes, } \\
\text { displays, salt/flour maps, artifacts, weaving, drying fruit, and making } \\
\text { soup). }\end{array}$ & 657 & 9 \\
\hline 13. Art-related activities (painting, drawing). & 770 & 12 \\
\hline $\begin{array}{l}\text { 14. Writing activities (journals, logs, letters to pen pals, letters } \\
\text { requesting information, writing plays or dialogue). }\end{array}$ & 647 & 8 \\
\hline
\end{tabular}




\section{Table 8 \\ Summary of Responses to Question 2 Comparison of Grade Level Rankings of Enjoyable Activities}

\begin{tabular}{|c|c|c|c|}
\hline \multirow[b]{2}{*}{ Activities } & \multicolumn{3}{|c|}{ Rankings } \\
\hline & Grades K-3 & Grades 4-6 & Grades 7-8 \\
\hline 1. Reading and discussing text. & 1 & 1 & 1 \\
\hline $\begin{array}{l}\text { 2. Reinforcing activities: seatwork (crossword } \\
\text { puzzles, fill-in-the-blank, matching, locating and } \\
\text { coloring correct answers, vocabulary and skill } \\
\text { reinforcement). }\end{array}$ & 3 & 3 & 2 \\
\hline $\begin{array}{l}\text { 3. Reinforcing activities: class discussion (open- } \\
\text { ended questions, reading and interpreting a map, } \\
\text { graph, cartoon, or paragraph). }\end{array}$ & 4 & 5 & 5 \\
\hline 4. Using games, simulations or computer games. & 9 & 11 & 13 \\
\hline 5. Viewing slides, filmstrips, movies, or videos. & 8 & 9 & 10 \\
\hline $\begin{array}{l}\text { 6. Listening to tapes, lectures, or dramatic } \\
\text { readings by the teacher or resource person. }\end{array}$ & 6 & 4 & 4 \\
\hline 7. Field trips. & 14 & 14 & 14 \\
\hline 8. Research project. & 2 & 2 & 3 \\
\hline $\begin{array}{l}\text { 9. Issue focused interaction (debate, mock trial, } \\
\text { panel discussions). }\end{array}$ & 5 & 6 & 11 \\
\hline $\begin{array}{l}\text { 10. Oral language experience (story-telling with } \\
\text { pictures or puppets, writing/singing songs, or } \\
\text { conducting structured interviews). }\end{array}$ & 12 & 8 & 6 \\
\hline $\begin{array}{l}\text { 11. Performing from scripts (plays, puppet } \\
\text { shows, pageants). }\end{array}$ & 10 & 10 & 7 \\
\hline $\begin{array}{l}\text { 12. Constructing/making (dioramas, panoramas, } \\
\text { shadow boxes, displays, salt/flour maps, artifacts, } \\
\text { weaving, drying fruit, and making soup). }\end{array}$ & 11 & 12 & 9 \\
\hline 13. Art-related activities (painting, drawing). & 13 & 13 & 12 \\
\hline $\begin{array}{l}\text { 14. Writing activities (journals, logs, letters to pen } \\
\text { pals, letters requesting information, writing plays } \\
\text { or dialogue). }\end{array}$ & 7 & 7 & 8 \\
\hline
\end{tabular}


Table 9

Summary of Responses to Question 3

Weighted Responses and Rankings of Preferred Activities for Grades K-3

\begin{tabular}{|c|c|c|}
\hline \multirow[b]{2}{*}{ Activities } & \multicolumn{2}{|c|}{ Grades K-3 } \\
\hline & $\begin{array}{c}\text { Weighted } \\
\text { Responses }\end{array}$ & Rankings \\
\hline 1. Reading and discussing text. & 419 & 2 \\
\hline $\begin{array}{l}\text { 2. Reinforcing activities: seatwork (crossword puzzles, fill-in-the- } \\
\text { blank, matching, locating and coloring correct answers, vocabulary } \\
\text { and skill reinforcement). }\end{array}$ & 492 & 3 \\
\hline $\begin{array}{l}\text { 3. Reinforcing activities: class discussion (open-ended questions, } \\
\text { reading and interpreting a map, graph, cartoon, or paragraph). }\end{array}$ & 599 & 7 \\
\hline 4. Using games, simulations or computer games. & 727 & 11 \\
\hline 5. Viewing slides, filmstrips, movies, or videos. & 556 & 6 \\
\hline $\begin{array}{l}\text { 6. Listening to tapes, lectures, or dramatic readings by the teacher or } \\
\text { resource person. }\end{array}$ & 519 & 5 \\
\hline 7. Field trips. & 831 & 14 \\
\hline 8. Research project. & 411 & 1 \\
\hline 9. Issue focused interaction (debate, mock trial, panel discussions). & 498 & 4 \\
\hline $\begin{array}{l}\text { 10. Oral language experience (story-telling with pictures or puppets, } \\
\text { writing/singing songs, or conducting structured interviews). }\end{array}$ & 811 & 13 \\
\hline 11. Performing from scripts (plays, puppet shows, pageants). & 695 & 10 \\
\hline $\begin{array}{l}\text { 12. Constructing/making (dioramas, panoramas, shadow boxes, } \\
\text { displays, salt/flour maps, artifacts, weaving, drying fruit, and making } \\
\text { soup). }\end{array}$ & 695 & 10 \\
\hline 13. Art-related activities (painting, drawing). & 758 & 12 \\
\hline $\begin{array}{l}\text { 14. Writing activities (journals, logs, letters to pen pals, letters } \\
\text { requesting information, writing plays or dialogue). }\end{array}$ & 633 & 8 \\
\hline
\end{tabular}




\begin{tabular}{|c|c|c|}
\hline \multirow[b]{2}{*}{ Activities } & \multicolumn{2}{|c|}{ Grades 4-6 } \\
\hline & $\begin{array}{c}\text { Weighted } \\
\text { Responses }\end{array}$ & Rankings \\
\hline 1. Reading and discussing text. & 537 & 4 \\
\hline $\begin{array}{l}\text { 2. Reinforcing activities: seatwork (crossword puzzles, fill-in-the- } \\
\text { blank, matching, locating and coloring correct answers, vocabulary } \\
\text { and skill reinforcement). }\end{array}$ & 425 & 1 \\
\hline $\begin{array}{l}\text { 3. Reinforcing activities: class discussion (open-ended questions, } \\
\text { reading and interpreting a map, graph, cartoon, or paragraph). }\end{array}$ & 688 & 11 \\
\hline 4. Using games, simulations or computer games. & 667 & 8 \\
\hline 5. Viewing slides, filmstrips, movies, or videos. & 533 & 3 \\
\hline $\begin{array}{l}\text { 6. Listening to tapes, lectures, or dramatic readings by the teacher or } \\
\text { resource person. }\end{array}$ & 508 & 2 \\
\hline 7. Field trips. & 824 & 14 \\
\hline 8. Research project. & 578 & 5 \\
\hline 9. Issue focused interaction (debate, mock trial, panel discussions). & 687 & 10 \\
\hline $\begin{array}{l}\text { 10. Oral language experience (story-telling with pictures or puppets, } \\
\text { writing/singing songs, or conducting structured interviews). }\end{array}$ & 694 & 12 \\
\hline 11. Performing from scripts (plays, puppet shows, pageants). & 600 & 7 \\
\hline $\begin{array}{l}\text { 12. Constructing/making (dioramas, panoramas, shadow boxes, } \\
\text { displays, salt/flour maps, artifacts, weaving, drying fruit, and making } \\
\text { soup). }\end{array}$ & 670 & 9 \\
\hline 13. Art-related activities (painting, drawing). & 580 & 6 \\
\hline $\begin{array}{l}\text { 14. Writing activities (journals, logs, letters to pen pals, letters } \\
\text { requesting information, writing plays or dialogue). }\end{array}$ & 760 & 13 \\
\hline
\end{tabular}


Table 11

Summary of Responses to Question 3

Weighted Responses and Rankings of Preferred Activities for Grades 7-8

\begin{tabular}{|c|c|c|}
\hline \multirow[b]{2}{*}{ Activities } & \multicolumn{2}{|c|}{ Grades 7-8 } \\
\hline & $\begin{array}{c}\text { Weighted } \\
\text { Responses }\end{array}$ & Rankings \\
\hline 1. Reading and discussing text. & 595 & 6 \\
\hline $\begin{array}{l}\text { 2. Reinforcing activities: seatwork (crossword puzzles, fill-in-the- } \\
\text { blank, matching, locating and coloring correct answers, vocabulary } \\
\text { and skill reinforcement). }\end{array}$ & 439 & 1 \\
\hline $\begin{array}{l}\text { 3. Reinforcing activities: class discussion (open-ended questions, } \\
\text { reading and interpreting a map, graph, cartoon, or paragraph). }\end{array}$ & 722 & 11 \\
\hline 4. Using games, simulations or computer games. & 654 & 9 \\
\hline 5. Viewing slides, filmstrips, movies, or videos. & 606 & 7 \\
\hline $\begin{array}{l}\text { 6. Listening to tapes, lectures, or dramatic readings by the teacher or } \\
\text { resource person. }\end{array}$ & 561 & 3 \\
\hline 7. Field trips. & 756 & 12 \\
\hline 8. Research project. & 706 & 10 \\
\hline 9. Issue focused interaction (debate, mock trial, panel discussions). & 792 & 14 \\
\hline $\begin{array}{l}\text { 10. Oral language experience (story-telling with pictures or puppets, } \\
\text { writing/singing songs, or conducting structured interviews). }\end{array}$ & 573 & 5 \\
\hline 11. Performing from scripts (plays, puppet shows, pageants). & 619 & 8 \\
\hline $\begin{array}{l}\text { 12. Constructing/making (dioramas, panoramas, shadow boxes, } \\
\text { displays, salt/flour maps, artifacts, weaving, drying fruit, and making } \\
\text { soup). }\end{array}$ & 568 & 4 \\
\hline 13. Art-related activities (painting, drawing). & 531 & 2 \\
\hline $\begin{array}{l}\text { 14. Writing activities (journals, logs, letters to pen pals, letters } \\
\text { requesting information, writing plays or dialogue). }\end{array}$ & 783 & 13 \\
\hline
\end{tabular}


Table 12

Summary of Responses to Question 3 Comparison of Grade Level Rankings of Preferred Activities

\begin{tabular}{|c|c|c|c|}
\hline \multirow[b]{2}{*}{ Activities } & \multicolumn{3}{|c|}{ Rankings } \\
\hline & Grades K-3 & Grades 4-6 & Grades 7-8 \\
\hline 1. Reading and discussing text. & 2 & 4 & 6 \\
\hline $\begin{array}{l}\text { 2. Reinforcing activities: seatwork (crossword } \\
\text { puzzles, fill-in-the-blank, matching, locating and } \\
\text { coloring correct answers, vocabulary and skill } \\
\text { reinforcement). }\end{array}$ & 3 & 1 & 1 \\
\hline $\begin{array}{l}\text { 3. Reinforcing activities: class discussion (open- } \\
\text { ended questions, reading and interpreting a map, } \\
\text { graph, cartoon, or paragraph). }\end{array}$ & 7 & 11 & 11 \\
\hline 4. Using games, simulations or computer games. & 11 & 8 & 9 \\
\hline 5. Viewing slides, filmstrips, movies, or videos. & 6 & 3 & 7 \\
\hline $\begin{array}{l}\text { 6. Listening to tapes, lectures, or dramatic } \\
\text { readings by the teacher or resource person. }\end{array}$ & 5 & 2 & 3 \\
\hline 7. Field trips. & 14 & 14 & 12 \\
\hline 8. Research project. & 1 & 5 & 10 \\
\hline $\begin{array}{l}\text { 9. Issue focused interaction (debate, mock trial, } \\
\text { panel discussions). }\end{array}$ & 4 & 10 & 14 \\
\hline $\begin{array}{l}\text { 10. Oral language experience (story-telling with } \\
\text { pictures or puppets, writing/singing songs, or } \\
\text { conducting structured interviews). }\end{array}$ & 13 & 12 & 5 \\
\hline $\begin{array}{l}\text { 11. Performing from scripts (plays, puppet } \\
\text { shows, pageants). }\end{array}$ & 10 & 7 & 8 \\
\hline $\begin{array}{l}\text { 12. Constructing/making (dioramas, panoramas, } \\
\text { shadow boxes, displays, salt/flour maps, artifacts, } \\
\text { weaving, drying fruit, and making soup). }\end{array}$ & 10 & 9 & 4 \\
\hline 13. Art-related activities (painting, drawing). & 12 & 6 & 2 \\
\hline $\begin{array}{l}\text { 14. Writing activities (journals, logs, letters to pen } \\
\text { pals, letters requesting information, writing plays } \\
\text { or dialogue). }\end{array}$ & 8 & 13 & 13 \\
\hline
\end{tabular}


Table 13

Summary of Responses to Research Questions 1 through 3

Comparisons of Rankings for Educational Value, Preferences, and

Perceived Enjoyment for Kindergarten - Grade 3

\begin{tabular}{|c|c|c|c|}
\hline \multirow[b]{2}{*}{ Activities } & \multicolumn{3}{|c|}{ Rankings } \\
\hline & $\begin{array}{l}\text { Educational } \\
\text { Value }\end{array}$ & $\begin{array}{l}\text { Preferred } \\
\text { Activity }\end{array}$ & $\begin{array}{c}\text { Enjoyable } \\
\text { Activity }\end{array}$ \\
\hline 1. Reading and discussing text. & 1 & 2 & 1 \\
\hline $\begin{array}{l}\text { 2. Reinforcing activities: seatwork (crossword } \\
\text { puzzles, fill-in-the-blank, matching, locating and } \\
\text { coloring correct answers, vocabulary and skill } \\
\text { reinforcement). }\end{array}$ & 2 & 3 & 3 \\
\hline $\begin{array}{l}\text { 3. Reinforcing activities: class discussion (open- } \\
\text { ended questions, reading and interpreting a map, } \\
\text { graph, cartoon, or paragraph). }\end{array}$ & 8 & 7 & 4 \\
\hline 4. Using games, simulations or computer games. & 11 & 11 & 9 \\
\hline 5. Viewing slides, filmstrips, movies, or videos. & 6 & 6 & 8 \\
\hline $\begin{array}{l}\text { 6. Listening to tapes, lectures, or dramatic } \\
\text { readings by the teacher or resource person. }\end{array}$ & 5 & 5 & 6 \\
\hline 7. Field trips. & 13 & 14 & 14 \\
\hline 8. Research project. & 3 & 1 & 2 \\
\hline $\begin{array}{l}\text { 9. Issue focused interaction (debate, mock trial, } \\
\text { panel discussions). }\end{array}$ & 4 & 4 & 5 \\
\hline $\begin{array}{l}\text { 10. Oral language experience (story-telling with } \\
\text { pictures or puppets, writing/singing songs, or } \\
\text { conducting structured interviews). }\end{array}$ & 14 & 13 & 12 \\
\hline $\begin{array}{l}\text { 11. Performing from scripts (plays, puppet } \\
\text { shows, pageants). }\end{array}$ & 12 & 10 & 10 \\
\hline $\begin{array}{l}\text { 12. Constructing/making (dioramas, panoramas, } \\
\text { shadow boxes, displays, salt/flour maps, artifacts, } \\
\text { weaving, drying fruit, and making soup). }\end{array}$ & 10 & 10 & 11 \\
\hline 13. Art-related activities (painting, drawing). & 9 & 12 & 13 \\
\hline $\begin{array}{l}\text { 14. Writing activities (journals, logs, letters to pen } \\
\text { pals, letters requesting information, writing plays } \\
\text { or dialogue). }\end{array}$ & 7 & 8 & 7 \\
\hline
\end{tabular}


Table 14

Summary of Responses to Research Questions 1 through 3

Comparisons of Rankings for Educational Value, Preferences, and

Perceived Student Enjoyment for Grades 4-6

\begin{tabular}{|c|c|c|c|}
\hline \multirow[b]{2}{*}{ Activities } & \multicolumn{3}{|c|}{ Rankings } \\
\hline & $\begin{array}{l}\text { Educational } \\
\text { Value }\end{array}$ & $\begin{array}{c}\text { Enjoyable } \\
\text { Activity }\end{array}$ & $\begin{array}{l}\text { Preferred } \\
\text { Activity }\end{array}$ \\
\hline 1. Reading and discussing text. & 4 & 1 & 4 \\
\hline $\begin{array}{l}\text { 2. Reinforcing activities: seatwork (crossword } \\
\text { puzzles, fill-in-the-blank, matching, locating and } \\
\text { coloring correct answers, vocabulary and skill } \\
\text { reinforcement). }\end{array}$ & 1 & 3 & 1 \\
\hline $\begin{array}{l}\text { 3. Reinforcing activities: class discussion (open- } \\
\text { ended questions, reading and interpreting a map, } \\
\text { graph, cartoon, or paragraph). }\end{array}$ & 13 & 5 & 11 \\
\hline 4. Using games, simulations or computer games. & 7 & 11 & 8 \\
\hline 5. Viewing slides, filmstrips, movies, or videos. & 5 & 9 & 3 \\
\hline $\begin{array}{l}\text { 6. Listening to tapes, lectures, or dramatic } \\
\text { readings by the teacher or resource person. }\end{array}$ & 3 & 4 & 2 \\
\hline 7. Field trips. & 14 & 14 & 14 \\
\hline 8. Research project. & 9 & 2 & 5 \\
\hline $\begin{array}{l}\text { 9. Issue focused interaction (debate, mock trial, } \\
\text { panel discussions). }\end{array}$ & 10 & 6 & 10 \\
\hline $\begin{array}{l}\text { 10. Oral language experience (story-telling with } \\
\text { pictures or puppets, writing/singing songs, or } \\
\text { conducting structured interviews). }\end{array}$ & 12 & 8 & 12 \\
\hline $\begin{array}{l}\text { 11. Performing from scripts (plays, puppet } \\
\text { shows, pageants). }\end{array}$ & 6 & 10 & 7 \\
\hline $\begin{array}{l}\text { 12. Constructing/making (dioramas, panoramas, } \\
\text { shadow boxes, displays, salt/flour maps, artifacts, } \\
\text { weaving, drying fruit, and making soup). }\end{array}$ & 8 & 12 & 9 \\
\hline 13. Art-related activities (painting, drawing). & 2 & 13 & 6 \\
\hline $\begin{array}{l}\text { 14. Writing activities (journals, logs, letters to pen } \\
\text { pals, letters requesting information, writing plays } \\
\text { or dialogue). }\end{array}$ & 11 & 7 & 13 \\
\hline
\end{tabular}


Table 15

Summary of Responses to Research Questions 1 through 3

Comparisons of Rankings for Educational Value, Preferences, and

Perceived Student Enjoyment for Grades 7-8

\begin{tabular}{|c|c|c|c|}
\hline \multirow[b]{2}{*}{ Activities } & \multicolumn{3}{|c|}{ Rankings } \\
\hline & $\begin{array}{l}\text { Educational } \\
\text { Value }\end{array}$ & $\begin{array}{c}\text { Enjoyable } \\
\text { Activity }\end{array}$ & $\begin{array}{l}\text { Preferred } \\
\text { Activity }\end{array}$ \\
\hline 1. Reading and discussing text. & 7 & 1 & 4 \\
\hline $\begin{array}{l}\text { 2. Reinforcing activities: seatwork (crossword } \\
\text { puzzles, fill-in-the-blank, matching, locating and } \\
\text { coloring correct answers, vocabulary and skill } \\
\text { reinforcement). }\end{array}$ & 1 & 2 & 1 \\
\hline $\begin{array}{l}\text { 3. Reinforcing activities: class discussion (open- } \\
\text { ended questions, reading and interpreting a map, } \\
\text { graph, cartoon, or paragraph). }\end{array}$ & 13 & 5 & 11 \\
\hline 4. Using games, simulations or computer games. & 6 & 13 & 8 \\
\hline 5. Viewing slides, filmstrips, movies, or videos. & 3 & 10 & 3 \\
\hline $\begin{array}{l}\text { 6. Listening to tapes, lectures, or dramatic } \\
\text { readings by the teacher or resource person. }\end{array}$ & 4 & 4 & 2 \\
\hline 7. Field trips. & 14 & 14 & 14 \\
\hline 8. Research project. & 12 & 3 & 5 \\
\hline $\begin{array}{l}\text { 9. Issue focused interaction (debate, mock trial, } \\
\text { panel discussions). }\end{array}$ & 11 & 11 & 10 \\
\hline $\begin{array}{l}\text { 10. Oral language experience (story-telling with } \\
\text { pictures or puppets, writing/singing songs, or } \\
\text { conducting structured interviews). }\end{array}$ & 9 & 6 & 12 \\
\hline $\begin{array}{l}\text { 11. Performing from scripts (plays, puppet } \\
\text { shows, pageants). }\end{array}$ & 5 & 7 & 7 \\
\hline $\begin{array}{l}\text { 12. Constructing/making (dioramas, panoramas, } \\
\text { shadow boxes, displays, salt/flour maps, artifacts, } \\
\text { weaving, drying fruit, and making soup). }\end{array}$ & 8 & 9 & 9 \\
\hline 13. Art-related activities (painting, drawing). & 2 & 12 & 6 \\
\hline $\begin{array}{l}\text { 14. Writing activities (journals, logs, letters to pen } \\
\text { pals, letters requesting information, writing plays } \\
\text { or dialogue). }\end{array}$ & 16 & 8 & 13 \\
\hline
\end{tabular}




\begin{tabular}{|c|c|c|}
\hline \multirow[b]{2}{*}{ Content Areas } & \multicolumn{2}{|c|}{ Rankings (and Tally) } \\
\hline & $\begin{array}{c}\text { Most } \\
\text { Preferred }\end{array}$ & $\begin{array}{c}\text { Least } \\
\text { Preferred }\end{array}$ \\
\hline Anthropology & & $22(33)$ \\
\hline Archeology & & $21(30)$ \\
\hline \multicolumn{3}{|l|}{ Career Education } \\
\hline Conflict Resolution & $4(33)$ & \\
\hline Current Events & $2(42)$ & \\
\hline Drug Education & $3(41)$ & \\
\hline \multicolumn{3}{|l|}{ Economics } \\
\hline \multicolumn{3}{|c|}{ Energy and Environmental Education } \\
\hline \multicolumn{3}{|l|}{ Future Studies } \\
\hline \multicolumn{3}{|l|}{ Gender Issues } \\
\hline \multicolumn{3}{|l|}{ Geography } \\
\hline \multicolumn{3}{|l|}{ Global Education } \\
\hline \multicolumn{3}{|l|}{ Humanities } \\
\hline Law-related Education & & $24(44)$ \\
\hline Multicultural Education & $1(46)$ & \\
\hline Philosophy & & $23(35)$ \\
\hline \multicolumn{3}{|l|}{ Political Science } \\
\hline \multicolumn{3}{|l|}{ Psychology } \\
\hline Religion & & $25(45)$ \\
\hline \multicolumn{3}{|l|}{ Sociology } \\
\hline \multicolumn{3}{|l|}{ State History } \\
\hline \multicolumn{3}{|l|}{ U. S. History } \\
\hline Values Education & $4(33)$ & \\
\hline \multicolumn{3}{|c|}{ Volunteer/required Social Service Projects } \\
\hline World History & & \\
\hline
\end{tabular}




\begin{tabular}{|c|c|c|}
\hline & Ranking & nd Tally) \\
\hline Content Areas & $\begin{array}{c}\text { Most } \\
\text { Preferred }\end{array}$ & $\begin{array}{c}\text { Least } \\
\text { Preferred }\end{array}$ \\
\hline Anthropology & & \\
\hline Archeology & & \\
\hline Career Education & & \\
\hline Conflict Resolution & & \\
\hline Current Events & $1(50)$ & \\
\hline Drug Education & $2(48)$ & \\
\hline Economics & & $21(27)$ \\
\hline Energy and Environmental Education & & \\
\hline Future Studies & & \\
\hline Gender Issues & & \\
\hline Geography & & \\
\hline Global Education & & \\
\hline Humanities & & \\
\hline Law-related Education & & $22(33)$ \\
\hline Multicultural Education & $3(34)$ & \\
\hline Philosophy & & $24(35)$ \\
\hline Political Science & & $23(34)$ \\
\hline Psychology & & \\
\hline Religion & & $25(45)$ \\
\hline Sociology & & \\
\hline State History & $4(31)$ & \\
\hline U. S. History & $5(26)$ & \\
\hline Values Education & & \\
\hline Volunteer/required Social Service Projects & & \\
\hline World History & & \\
\hline
\end{tabular}


Summary of Responses to Question 4

The Five Most Preferred and Five Least Preferred Content Areas for Grades 7-8

\begin{tabular}{|c|c|c|}
\hline \multirow[b]{2}{*}{ Content Areas } & \multicolumn{2}{|c|}{ Rankings (and Tally) } \\
\hline & $\begin{array}{c}\text { Most } \\
\text { Preferred }\end{array}$ & $\begin{array}{c}\text { Least } \\
\text { Preferred }\end{array}$ \\
\hline \multicolumn{3}{|l|}{ Anthropology } \\
\hline Archeology & & $21(30)$ \\
\hline Career Education & $3(35)$ & \\
\hline \multicolumn{3}{|l|}{ Conflict Resolution } \\
\hline Current Events & $1(50)$ & \\
\hline Drug Education & $2(45)$ & \\
\hline \multicolumn{3}{|l|}{ Economics } \\
\hline \multicolumn{3}{|l|}{ Energy and Environmental Education } \\
\hline \multicolumn{3}{|l|}{ Future Studies } \\
\hline \multicolumn{3}{|l|}{ Gender Issues } \\
\hline \multicolumn{3}{|l|}{ Geography } \\
\hline \multicolumn{3}{|l|}{ Global Education } \\
\hline \multicolumn{3}{|l|}{ Humanities } \\
\hline Law-related Education & & $24(36)$ \\
\hline Multicultural Education & $4(30)$ & \\
\hline Philosophy & & $23(35)$ \\
\hline Political Science & & $22(34)$ \\
\hline \multicolumn{3}{|l|}{ Psychology } \\
\hline Religion & & $25(52)$ \\
\hline \multicolumn{3}{|l|}{ Sociology } \\
\hline \multicolumn{3}{|l|}{ State History } \\
\hline U. S. History & $5(28)$ & \\
\hline \multicolumn{3}{|l|}{ Values Education } \\
\hline \multicolumn{3}{|l|}{ Volunteer/required Social Service Projects } \\
\hline World History & & \\
\hline
\end{tabular}


Summary of Responses to Question 4

Comparison of Most Preferred Content Areas for the Various Elementary Grades

\begin{tabular}{|l|c|c|c|}
\cline { 2 - 4 } \multicolumn{1}{c|}{} & \multicolumn{2}{c|}{ Most Preferred } \\
\hline Content Areas & Grades K-3 & Grades 4-6 & Grades 7-8 \\
\hline Anthropology & & & \\
\hline Archeology & & & \\
\hline Career Education & & & 3 \\
\hline Conflict Resolution & 4 & & \\
\hline Current Events & 2 & 1 & 1 \\
\hline Drug Education & 3 & 2 & \\
\hline Economics & & & \\
\hline Energy and Environmental Education & & & \\
\hline Future Studies & & & \\
\hline Gender Issues & & & \\
\hline Geography & & & \\
\hline Global Education & & & \\
\hline Humanities & & & \\
\hline Law-related Education & & & \\
\hline Multicultural Education & & & \\
\hline Philosophy & & & \\
\hline Political Science & & & \\
\hline Psychology & & & \\
\hline Religion & & & \\
\hline Sociology & & & \\
\hline State History & & & \\
\hline U. S. History & & & \\
\hline Values Education & & & \\
\hline Volunteer/required Social Service Projects & & & \\
\hline World History & & & \\
\hline
\end{tabular}


Social Studies Activities and Content 108

Table 20

Summary of Responses to Question 4

Comparison of Least Preferred Content Areas for the Various Elementary Grades

\begin{tabular}{|l|c|c|c|}
\cline { 2 - 4 } \multicolumn{1}{c|}{} & \multicolumn{2}{c|}{ Least Preferred } \\
\hline Content Areas & Grades K-3 & Grades 4-6 & Grades 7-8 \\
\hline Anthropology & 22 & & \\
\hline Archeology & & & 21 \\
\hline Career Education & & & \\
\hline Conflict Resolution & & & \\
\hline Current Events & & & \\
\hline Drug Education & & 21 & \\
\hline Economics & & & \\
\hline Energy and Environmental Education & & & \\
\hline Future Studies & & & \\
\hline Gender Issues & & & \\
\hline Geography & & & \\
\hline Global Education & & & \\
\hline Humanities & 24 & 22 & \\
\hline Law-related Education & & & \\
\hline Multicultural Education & & & \\
\hline Philosophy & & & \\
\hline Political Science & & & \\
\hline Psychology & & & \\
\hline Religion & & & \\
\hline Sociology & & & \\
\hline State History & & & \\
\hline U. S. History & & & \\
\hline Values Education & & & \\
\hline Volunteer/required Social Service Projects & & \\
\hline World History & & & \\
\hline
\end{tabular}




\section{Table 21}

Summary of Responses

Comparisons of Rankings for Educational Value, Preferences, and

Perceived Student Enjoyment for Kindergarten - Grade 8

\begin{tabular}{|c|c|c|c|c|c|c|c|c|c|}
\hline \multirow[b]{2}{*}{ Activities } & \multicolumn{3}{|c|}{$\begin{array}{l}\text { Educational } \\
\text { Value }\end{array}$} & \multicolumn{3}{|c|}{$\begin{array}{l}\text { Preferred } \\
\text { Activity }\end{array}$} & \multicolumn{3}{|c|}{$\begin{array}{l}\text { Perceived } \\
\text { Enjoyment }\end{array}$} \\
\hline & $\mathrm{K}-3$ & 4-6 & $7-8$ & $\mathrm{~K}-3$ & $4-6$ & $7-8$ & $\mathrm{~K}-3$ & $4-6$ & $7-8$ \\
\hline 1. Reading and discussing text. & 1 & 4 & 7 & 1 & 1 & 1 & 2 & 4 & 6 \\
\hline $\begin{array}{l}\text { 2. Reinforcing activities: seatwork (crossword } \\
\text { puzzles, fill-in-the-blank, matching, locating and } \\
\text { coloring correct answers, vocabulary and skill } \\
\text { reinforcement). }\end{array}$ & 2 & 1 & 1 & 3 & 3 & 2 & 3 & 1 & 1 \\
\hline $\begin{array}{l}\text { 3. Reinforcing activities: class discussion (open- } \\
\text { ended questions, reading and interpreting a map, } \\
\text { graph, cartoon, or paragraph). }\end{array}$ & 8 & 13 & 13 & 4 & 5 & 5 & 7 & 11 & 11 \\
\hline 4. Using games, simulations or computer games. & 11 & 7 & 6 & 9 & 11 & 13 & 11 & 8 & 9 \\
\hline 5. Viewing slides, filmstrips, movies, or videos. & 6 & 5 & 3 & 8 & 9 & 10 & 6 & 3 & 7 \\
\hline $\begin{array}{l}\text { 6. Listening to tapes, lectures, or dramatic } \\
\text { readings by the teacher or resource person. }\end{array}$ & 5 & 3 & 4 & 6 & 4 & 4 & 5 & 2 & 3 \\
\hline 7. Field trips. & 13 & 14 & 14 & 14 & 14 & 14 & 14 & 14 & 12 \\
\hline 8. Research project. & 3 & 9 & 12 & 2 & 2 & 3 & 1 & 5 & 10 \\
\hline $\begin{array}{l}\text { 9. Issue focused interaction (debate, mock trial, } \\
\text { panel discussions). }\end{array}$ & 4 & 10 & 11 & 5 & 6 & 11 & 4 & 10 & 14 \\
\hline $\begin{array}{l}\text { 10. Oral language experience (story-telling with } \\
\text { pictures or puppets, writing/singing songs, or } \\
\text { conducting structured interviews). }\end{array}$ & 14 & 12 & 9 & 12 & 8 & 6 & 13 & 12 & 5 \\
\hline $\begin{array}{l}\text { 11. Performing from scripts (plays, puppet } \\
\text { shows, pageants). }\end{array}$ & 12 & 6 & 5 & 10 & 10 & 7 & 10 & 7 & 8 \\
\hline $\begin{array}{l}\text { 12. Constructing/making (dioramas, panoramas, } \\
\text { shadow boxes, displays, salt/flour maps, artifacts, } \\
\text { weaving, drying fruit, and making soup). }\end{array}$ & 10 & 8 & 8 & 11 & 12 & 9 & 10 & 9 & 4 \\
\hline 13. Art-related activities (painting, drawing). & 9 & 2 & 2 & 13 & 13 & 12 & 12 & 6 & 2 \\
\hline $\begin{array}{l}\text { 14. Writing activities (journals, logs, letters to pen } \\
\text { pals, letters requesting information, writing plays } \\
\text { or dialogue). }\end{array}$ & 7 & 11 & 10 & 7 & 7 & 8 & 8 & 13 & 13 \\
\hline
\end{tabular}


Table 22

Summary of Secondary Social Studies Teachers' Responses

Comparisons of Rankings for Educational Value, Preferences, and

Perceived Student Enjoyment for Secondary Grades

(Murray, 1997)

\begin{tabular}{|c|c|c|c|}
\hline & $\begin{array}{c}\text { Educational } \\
\text { Value }\end{array}$ & $\begin{array}{l}\text { Preferred } \\
\text { Activity }\end{array}$ & $\begin{array}{l}\text { Perceived } \\
\text { Enjoyment }\end{array}$ \\
\hline Activities & \multicolumn{3}{|c|}{ Secondary Grades } \\
\hline 1. Reading and discussing text. & 11 & 4 & 5 \\
\hline $\begin{array}{l}\text { 2. Reinforcing activities: seatwork (crossword } \\
\text { puzzles, fill-in-the-blank, matching, locating and } \\
\text { coloring correct answers, vocabulary and skill } \\
\text { reinforcement). }\end{array}$ & 1 & 3 & 1 \\
\hline $\begin{array}{l}\text { 3. Reinforcing activities: class discussion (open- } \\
\text { ended questions, reading and interpreting a map, } \\
\text { graph, cartoon, or paragraph). }\end{array}$ & 14 & 7 & 14 \\
\hline 4. Using games, simulations or computer games. & 6 & 13 & 11 \\
\hline 5. Viewing slides, filmstrips, movies, or videos. & 9 & 12 & 9 \\
\hline $\begin{array}{l}\text { 6. Listening to tapes, lectures, or dramatic } \\
\text { readings by the teacher or resource person. }\end{array}$ & 13 & 6 & 12 \\
\hline 7. Field trips. & 3 & 14 & 7 \\
\hline 8. Research project. & 12 & 1 & 2 \\
\hline $\begin{array}{l}\text { 9. Issue focused interaction (debate, mock trial, } \\
\text { panel discussions). }\end{array}$ & 7 & 9 & 10 \\
\hline $\begin{array}{l}\text { 10. Oral language experience (story-telling with } \\
\text { pictures or puppets, writing/singing songs, or } \\
\text { conducting structured interviews). }\end{array}$ & NA & NA & NA \\
\hline $\begin{array}{l}\text { 11. Performing from scripts (plays, puppet } \\
\text { shows, pageants). }\end{array}$ & 2 & 11 & 6 \\
\hline $\begin{array}{l}\text { 12. Constructing/making (dioramas, panoramas, } \\
\text { shadow boxes, displays, salt/flour maps, artifacts, } \\
\text { weaving, drying fruit, and making soup). }\end{array}$ & NA & NA & NA \\
\hline 13. Art-related activities (painting, drawing). & NA & NA & NA \\
\hline $\begin{array}{l}\text { 14. Writing activities (journals, logs, letters to pen } \\
\text { pals, letters requesting information, writing plays } \\
\text { or dialogue). }\end{array}$ & 4 & 5 & 3 \\
\hline
\end{tabular}


Table 23

Summary of In-Service Social Studies Teachers' Reponses

Comparisons of Rankings for Educational Value, Preferences, and

Perceived Student Enjoyment for Kindergarten - Grade 8

(Alleman and Brophy, 1995)

\begin{tabular}{|c|c|c|c|c|c|c|c|c|c|}
\hline \multirow[b]{2}{*}{ Activities } & \multicolumn{3}{|c|}{$\begin{array}{c}\text { Educational } \\
\text { Value }\end{array}$} & \multicolumn{3}{|c|}{$\begin{array}{c}\text { Preferred } \\
\text { Activity }\end{array}$} & \multicolumn{3}{|c|}{$\begin{array}{l}\text { Perceived } \\
\text { Enjoyment }\end{array}$} \\
\hline & $\mathrm{K}-3$ & $4-6$ & $7-8$ & $\mathrm{~K}-3$ & $4-6$ & $7-8$ & $\mathrm{~K}-3$ & $4-6$ & $7-8$ \\
\hline 1. Reading and discussing text. & 2 & 3 & 6 & 1.5 & 2 & 2 & 3 & 2 & 4 \\
\hline $\begin{array}{l}\text { 2. Reinforcing activities: seatwork (crossword } \\
\text { puzzles, fill-in-the-blank, matching, locating and } \\
\text { coloring correct answers, vocabulary and skill } \\
\text { reinforcement). }\end{array}$ & 1 & 1 & 2 & 1.5 & 1 & 1 & 1 & 1 & 1 \\
\hline $\begin{array}{l}\text { 3. Reinforcing activities: class discussion (open- } \\
\text { ended questions, reading and interpreting a map, } \\
\text { graph, cartoon, or paragraph). }\end{array}$ & $\begin{array}{r}12 . \\
5\end{array}$ & 12 & 14 & 9.5 & 6.5 & 11 & 13 & 12 & 12 \\
\hline 4. Using games, simulations or computer games. & 6.5 & 7 & 7 & 11 & 12 & 10 & 8 & 6 & 9 \\
\hline 5. Viewing slides, filmstrips, movies, or videos. & 10 & 8 & 9 & $\begin{array}{r}12 . \\
5 \\
\end{array}$ & 8 & 6 & 10 & 9 & 7 \\
\hline $\begin{array}{l}\text { 6. Listening to tapes, lectures, or dramatic } \\
\text { readings by the teacher or resource person. }\end{array}$ & 4 & 6 & 4.5 & 4 & 3.5 & 4 & 3 & 3.5 & 2.5 \\
\hline 7. Field trips. & $\begin{array}{r}12 . \\
5\end{array}$ & 14 & 11 & 14 & 14 & 14 & 12 & 14 & 11 \\
\hline 8. Research project. & 8 & 9 & 10 & 3 & 3.5 & 5 & 7 & 7 & 5.5 \\
\hline $\begin{array}{l}\text { 9. Issue focused interaction (debate, mock trial, } \\
\text { panel discussions). }\end{array}$ & 6.5 & 13 & 12 & 5 & 9 & 13 & 4 & 10 & 13 \\
\hline $\begin{array}{l}\text { 10. Oral language experience (story-telling with } \\
\text { pictures or puppets, writing/singing songs, or } \\
\text { conducting structured interviews). }\end{array}$ & 14 & 11 & 8 & 9.5 & 10 & 9 & 11 & 11 & 10 \\
\hline $\begin{array}{l}\text { 11. Performing from scripts (plays, puppet } \\
\text { shows, pageants). }\end{array}$ & 5 & 5 & 3 & 6 & 6.5 & 7 & 5.5 & 5 & 5.5 \\
\hline $\begin{array}{l}\text { 12. Constructing/making (dioramas, panoramas, } \\
\text { shadow boxes, displays, salt/flour maps, artifacts, } \\
\text { weaving, drying fruit, and making soup). }\end{array}$ & 9 & 4 & 4.5 & $\begin{array}{r}12 . \\
5\end{array}$ & 13 & 8 & 9 & 8 & 8 \\
\hline 13. Art-related activities (painting, drawing). & 3 & 2 & 1 & 8 & 5 & 3 & 5.5 & 3.5 & 2.5 \\
\hline $\begin{array}{l}\text { 14. Writing activities (journals, logs, letters to pen } \\
\text { pals, letters requesting information, writing plays } \\
\text { or dialogue). }\end{array}$ & 11 & 11 & 13 & 7 & 11 & 12 & 14 & 13 & 14 \\
\hline
\end{tabular}




\section{Table 24}

Tallied Objectives for Goals and Objectives for West Virginia Schools

(Marockie, 1995)

Key to Table $24 \quad \cdot=$ Titled subsection listing objectives (Law-related Education and Political Science were subsumed under Civics)

- = Listed objective identified by author to a content area

Note: Study skills and computer technology objectives are included in West Virginia Social Studies Education Goals and Objectives but not included here since they were not included in the questionnaire given. 
Table 24

Tallied Objectives for Goals and Objectives for West Virginia Schools

(Marockie, 1995)

\begin{tabular}{|c|c|c|c|c|c|c|c|c|c|}
\hline \multirow[b]{2}{*}{ Content Areas } & \multicolumn{4}{|c|}{ Grades K-3 } & \multicolumn{3}{|c|}{ Grades 4-6 } & \multicolumn{2}{|c|}{ Grades 7-8 } \\
\hline & K & 1 & 2 & 3 & 4 & 5 & 6 & 7 & 8 \\
\hline \multicolumn{10}{|l|}{ Anthropology } \\
\hline Archeology & & & & - & & & & & \\
\hline Career Education & & & & & & & & & $\cdot$ \\
\hline Conflict Resolution & & $\cdot$ & - & & - & & & & \\
\hline Current Events & & & • & • & & & & & \\
\hline \multicolumn{10}{|l|}{ Drug Education } \\
\hline Economics & • & • & • & - & • & • & • & - & - \\
\hline Energy and Environmental Education & & - & • & • & & & • & • & \\
\hline Future Studies & & & & & & & • & - & \\
\hline Gender Issues & & & - & & & & • & • & - \\
\hline Geography & - & - & - & • & • & $\cdot$ & • & • & - \\
\hline Global Education & & & & & & & • & • & \\
\hline Humanities & • & - & • & - & • & • & • & - & - \\
\hline Law-related Education & • & • & $\cdot$ & • & • & • & • & - & $\cdot$ \\
\hline Multicultural Education & & • & • & - & - & - & • & - & - \\
\hline Philosophy & & & & & & & • & & \\
\hline Political Science & & $\cdot$ & $\cdot$ & • & • & $\cdot$ & • & - & $\cdot$ \\
\hline Psychology & & & & & & & & - & \\
\hline Religion & & & & & & & • & • & • \\
\hline Sociology & $\cdot$ & $\cdot$ & $\cdot$ & $\cdot$ & - & $\cdot$ & • & - & $\cdot$ \\
\hline State History & & & & & • & & & & $\cdot$ \\
\hline U. S. History & & • & • & $\bullet$ & $\cdot$ & - & • & & \\
\hline Values Education & • & • & • & - & - & - & • & - & - \\
\hline Volunteer/required Social Service Projects & & & & - & • & & & & $\cdot$ \\
\hline World History & - & - & & & - & - & - & - & \\
\hline
\end{tabular}




\section{Table 25}

Ranked Objectives for Goals and Objectives for West Virginia Schools

(Marockie, 1995)

Note: Study skills and computer technology objectives are included in West Virginia Social Studies Educational Goals and Objectives but not included here since they were not included in the questionnaire given to respondents. 


\section{Table 25}

Ranked Objectives for Goals and Objectives for West Virginia Schools

(Marockie, 1995)

1 is highest ranking

\begin{tabular}{|l|c|c|c|}
\hline Content Areas & Grades K-3 & Grades 4-6 & Grades 7-8 \\
\hline Anthropology & & & \\
\hline Archeology & & & \\
\hline Career Education & & & \\
\hline Conflict Resolution & & & \\
\hline Current Events & & & \\
\hline Drug Education & 1 & 1 & 1 \\
\hline Economics & & & \\
\hline Energy and Environmental Education & & & \\
\hline Future Studies & & & \\
\hline Gender Issues & 1 & 1 & \\
\hline Geography & 5 & & \\
\hline Global Education & 1 & & \\
\hline Humanities & & & \\
\hline Law-related Education & & & \\
\hline Multicultural Education & & & \\
\hline Philosophy & & & \\
\hline Political Science & & & \\
\hline Psychology & & & \\
\hline Religion & & & \\
\hline Sociology & & & \\
\hline State History & & & \\
\hline U. S. History & & & \\
\hline Values Education & & & \\
\hline Volunteer/required Social Service Projects & & & \\
\hline World History & & & \\
\hline & & & \\
\hline
\end{tabular}

